\title{
The Lavrion Mines: A Unique Site of Geological and Mineralogical Heritage
}

\author{
Panagiotis Voudouris ${ }^{1, *(\mathbb{D}}$, Vasilios Melfos $\left.{ }^{2} \mathbb{(}\right)$, Constantinos Mavrogonatos ${ }^{1}\left(\mathbb{D}\right.$, Adonis Photiades ${ }^{3}{ }^{(D)}$, \\ Eugenia Moraiti $^{3}$, Branko Rieck ${ }^{4}$, Uwe Kolitsch ${ }^{5}$, Alexandre Tarantola $\left.{ }^{6}{ }^{(}\right)$, Christophe Scheffer ${ }^{7}$, Denis Morin $8{ }^{8}$,

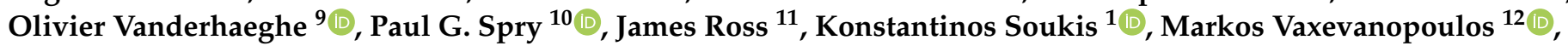 \\ Igor V. Pekov ${ }^{13}$, Nikita V. Chukanov ${ }^{14}$, Andreas Magganas ${ }^{1}$, Marianna Kati ${ }^{1}$, Athanasios Katerinopoulos ${ }^{1}$ and \\ Stefanos Zaimis ${ }^{15}$
}

check for updates

Citation: Voudouris, P.; Melfos, V.; Mavrogonatos, C.; Photiades, A.; Moraiti, E.; Rieck, B.; Kolitsch, U.; Tarantola, A.; Scheffer, C.; Morin, D.; et al. The Lavrion Mines: A Unique Site of Geological and Mineralogical Heritage. Minerals 2021, 11, 76. https://doi.org/10.3390/min11010076

Received: 23 December 2020

Accepted: 11 January 2021

Published: 14 January 2021

Publisher's Note: MDPI stays neutral with regard to jurisdictional claims in published maps and institutional affiliations.

Copyright: (c) 2021 by the authors. Licensee MDPI, Basel, Switzerland. This article is an open access article distributed under the terms and conditions of the Creative Commons Attribution (CC BY) license (https:// creativecommons.org/licenses/by/ $4.0 /)$.
1 Faculty of Geology \& Geoenvironment, National and Kapodistrian University of Athens, 15784 Athens, Greece; kmavrogon@geol.uoa.gr (C.M.); soukis@geol.uoa.gr (K.S.); magganas@geol.uoa.gr (A.M.); kati@geol.uoa.gr (M.K.); akaterin@geol.uoa.gr (A.K.)

2 Faculty of Geology, Aristotle University of Thessaloniki, 54124 Thessaloniki, Greece; melfosv@geo.auth.gr

3 Hellenic Survey of Geology and Mineral Exploration (HSGME), 13677 Acharnae, Greece; fotiadis@igme.gr (A.P.); moraiti@igme.gr (E.M.)

4 Institut für Mineralogie und Kristallographie, Universität Wien, 1090 Wien, Austria; branko.rieck@live.at

5 Mineralogisch-Petrographische Abteilung, Naturhistorisches Museum, 1010 Wien, Austria; uwe.kolitsch@nhm-wien.ac.at

6 Faculté des Sciences et Technologies, CNRS, GeoRessources UMR 7359, Université de Lorraine, 54506 Vandoeuvre-lès-Nancy, France; alexandre.tarantola@univ-lorraine.fr

7 Département de Géologie et de Génie Géologique, Université Laval, Québec, QC G1V 0A6, Canada; christophe.scheffer.1@ulaval.ca

8 HISCANT-MA, Université de Lorraine, 54015 Nancy, France; denis.morin@univ-lorraine.fr

9 Géosciences Environnement Toulouse (GET), CNRS, Université de Toulouse, 31400 Toulouse, France; Olivier.VANDERHAEGHE@Get.omp.eu

10 Department of Geological and Atmospheric Sciences, Iowa State University, Ames, IA 50011, USA; pgspry@iastate.edu

11 School of Earth Sciences, University of Western Australia, Perth 6907, Australia; jrhross@bigpond.com

12 École Normale Supérieure de Lyon, Laboratoire de Géologie de Lyon, Terre, Planète, Environnement, 69364 Lyon, France; vaxevanopoulos@gmail.com

13 Faculty of Geology, Moscow State University, Vorobievy Gory, 119991 Moscow, Russia; igorpekov@mail.ru

14 Institute of Problems of Chemical Physics, Russian Academy of Sciences, 142432 Moscow, Russia; nikchukanov@yandex.ru

15 Institut für Mineralogie, TU Bergakademie Freiberg, 09599 Freiberg, Germany; szaimis@gmail.com

* Correspondence: voudouris@geol.uoa.gr; Tel.: +30-21-07274129

\begin{abstract}
The Lavrion area corresponds to the western part of the Attic-Cycladic metamorphic belt, in the back-arc region of the active Hellenic subduction zone. Between the Eocene and the Miocene, metamorphic rocks (mainly marbles and schists) underwent several stages of metamorphism and deformation due to collision and collapse of the Cycladic belt. Exhumation during the Miocene was accommodated by the movement of a large-scale detachment fault system, which also enhanced emplacement of magmatic rocks, leading to the formation of the famous Lavrion silver deposits. The area around the mines shows the stacking of nappes, with ore deposition mainly localized within the marbles, at marble-schist contacts, below, within, or above the detachment. The Lavrion deposit comprises five genetically-related but different styles of mineralization, a feature never observed in another ore deposit elsewhere, containing the highest number of different elements of any known mining district. The local geology, tectonic, and magmatic activity were fundamental factors in determining how and when the mineralization formed. Other key factors, such as the rise and the fall of sea level, which resulted from climate change over the last million years, were also of major importance for the subsequent surface oxidation at Lavrion that created an unmatched diversity of secondary minerals. As a result, the Lavrion deposit contains 638 minerals of which Lavrion is type-locality for 23 of them, which is nearly $12 \%$ of all known species. Apart from being famous for its silver exploitation, this mining district contains more minerals than any other district on Earth.
\end{abstract}


The unique geological, mineralogical, and educational (mining, archaeological, and environmental) features suggest that it is highly suitable to be developed as a future UNESCO Global Geopark.

Keywords: Lavrion; Attica; minerals; ore deposits; geoheritage; cultural heritage; geotope

\section{Introduction}

Minerals from micromount up to megacryst size are among the most spectacular collectable objects exhibited in museums and private collections worldwide. In Greece, mineral species of extraordinary aesthetic and scientific value occur in several localities but occur mainly from three ancient mining districts: the Lavrion mines in Attica, the Serifos Island in the Aegean, and the Chalkidiki mines in northern Greece [1-6] (Figure 1). All three districts display some specific geological and mineralogical features, which are closely related to magma emplacement and ore mineralization along various extensional low-angle detachment fault systems [7-11]. For example, the Serifos island contains superb specimens of prase (e.g., the green quartz variety) and ilvaite hosted within a world-class hedenbergitic skarn. In the carbonate-replacement deposits in the Chalkidiki area, pyrite crystals up to $50 \mathrm{~cm}$ size are associated with quartz and rhodochrosite. Compared to the above two districts, the Lavrion $\mathrm{Pb}-\mathrm{Zn}-\mathrm{Cu}-\mathrm{Ag}$ deposit is characterized by an extraordinary suite of minerals and exemplary mining and archaeological features. From a mineralogical stand point, secondary minerals from the Lavrion district are famous, not only with respect to their color and crystal size, but because the district is the type-locality for 23 species (e.g., first discovered in this place) and/or assemblages with various pseudomorphs among mineral species (e.g., $[2,5,12])$. From an archeological point of view, the Lavrion district is famous for the exploitation of silver-rich lead ore during ancient times [13-15]. The Lavrion deposit was exploited by innumerable surface and shallow workings, $>1000$ ancient mine shafts, and extensive underground workings [16-19]. According to Ross et al. [19], direct evidence of mining dates from the third millennium BC [14], whereas indirect evidence, such as $\mathrm{Pb}$ isotopes and occurrences of litharge [20], indicate the commencement of mining in the fourth millennium BC. This continued, at least intermittently, until about $100 \mathrm{BC}$ with minor mining activities occurring until the Late Roman period $[14,15]$. The mining activities culminated during the Classical period (sixth to fourth century $\mathrm{BC}$ ) at the Kamariza area [14]. The area was not exploited again until 1864, when Andreas Kordellas and Giovanni Battista Serpieri started operations [14]. Modern mining of the district was conducted by the "Greek Metal Works Company of Lavrio" and the "Compagnie Française des Mines du Laurium" (CFML) until 1977 [14]. At least 2.3 million tons of lead and 7800 tons of silver were extracted from ore with grades of up to $20 \mathrm{wt} \% \mathrm{~Pb}$ and up to $400 \mathrm{~g} / \mathrm{t} \mathrm{Ag}$ during ancient and modern times [14].

The Lavrion district is considered as a potential UNESCO Global Geopark, since it fulfills all scientific, educational, cultural, and touristic criteria necessary for its characterization as a geopark [21-29]. At present, there are 147 UNESCO Global Geoparks in 41 countries. There are five UNESCO Global Geoparks in: Lesvos island; Psiloritis and Sitia in Crete; Chelmos-Vouraikos at Peloponnese; and Vikos-Aoos in Epirus (e.g., [30,31]) (Figure 1). These Greek geoparks combine extraordinary geological, paleontological, and natural features; however, in the authors' opinion, they are less spectacular when compared to Lavrion. The latter is unique, since there is no other area on Earth with such spectacular mineralogical, geological, mining, and archaeological characteristics.

The history, geology, structure, mineralogy, and deep supergene alteration of the Lavrion mineralization have been previously described by Marinos and Petrascheck [9], Leleu et al. [32], Economou et al. [33], Photiades and Carras [34], Photiades and Saccani [35], Skarpelis [36], Voudouris et al. [37,38], Skarpelis and Argyraki [39], Bonsall et al. [40], Spry et al. [41], Berger et al. [11], Scheffer et al. [42-44], and Ross et al. [19,45]. The aim of this article is to expand on previous work and summarize the current state of knowl- 
edge on the geology, the mineralization, and the supergene mineralogy of the Lavrion deposit and to highlight its unique geological, mineralogical, archaeological, mining, and educational features.
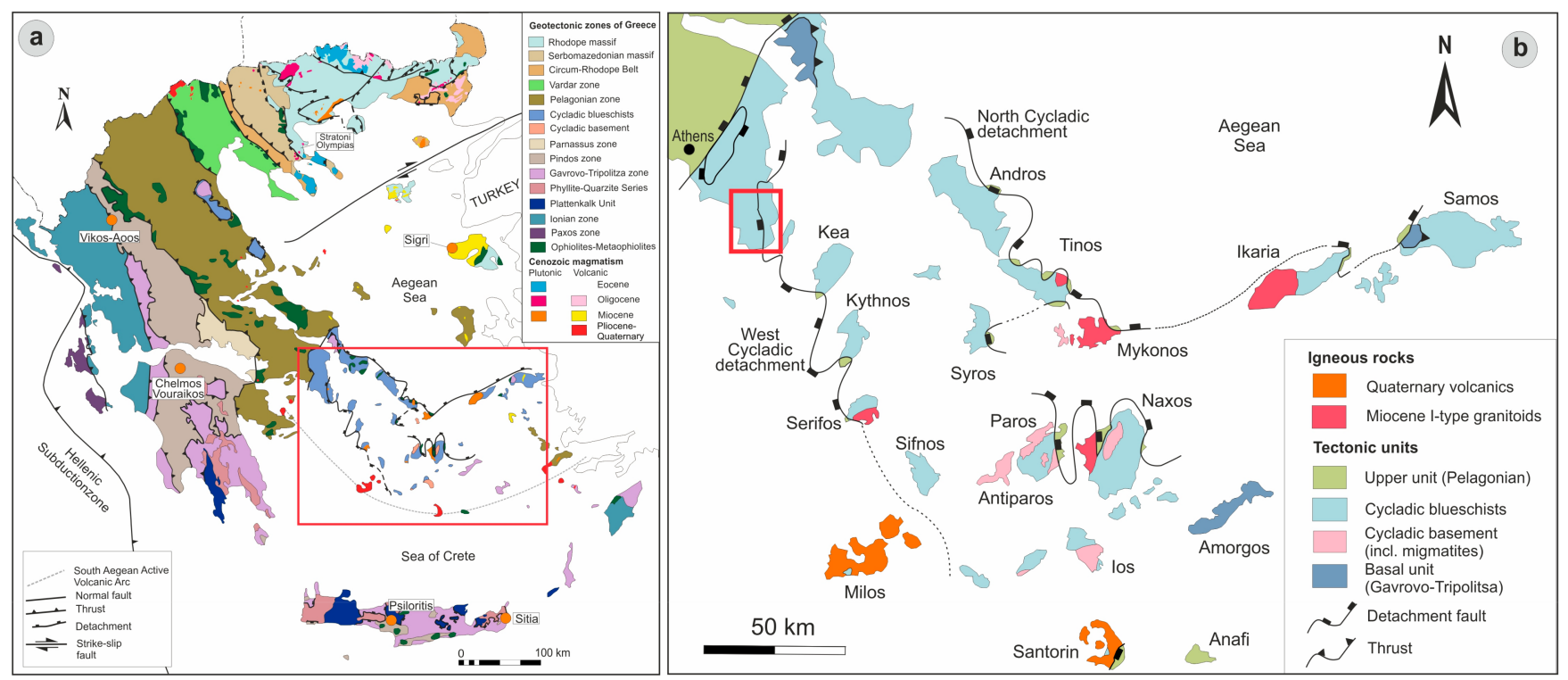

Figure 1. Geological map of (a) Greece and (b) the Attic-Cycladic belt from Jolivet et al. [46], Wind et al. [47], Grasemann et al. [48], and modified after Ottens and Voudouris [5]. The location of the Sigri at Lesvos, Psiloritis, ChelmosVouraikos, Vikos-Aoos, and Sitia UNESCO Global Geoparks are shown, while the Lavrion area is marked with a red square in Figure $1 \mathrm{~b}$ and described in detail in Figure 2. Other mining sites with exemplary geological and mineralogical characteristics include Stratoni and Olympias at Chalkidiki, and Serifos, Syros, and Naxos islands.

\section{Regional Geology}

The Lavrion district belongs to the Attic-Cycladic crystalline belt, which represents a polymetamorphic terrane within the Alpine orogen of the Hellenides [46,49-51] (Figure 1). The latter were formed as a result of convergence between the African and the Eurasian plates since the Late Jurassic to the present above the Hellenic subduction zone. Since ca. $35 \mathrm{Ma}$ ago, the geodynamic evolution of the Aegean area includes slab roll-back, resulting in the southward migration of magmatic activity from northern Greece to the active South Aegean volcanic arc. As a result of slab roll-back, orogenic collapse and the opening of the Aegean back-arc basin allowed for the post-orogenic exhumation of the crust as metamorphic core complexes, such as in the Cyclades, associated with voluminous magmatism [46]. Three major units, the Cycladic basement, the Cycladic blueschist unit, and the Upper tectonic unit, can be distinguished, from bottom to top, in the Attic-Cycladic belt (e.g., [46,47,52], Figure 1b), with two of them, mainly the Cycladic blueschist- and the Upper tectonic units, being exposed in the Lavrion area. In addition, the so-called Basal unit is exposed on Amorgos, Samos, and Evia islands (Figure 1b). The Cycladic blueschist unit consists of a volcano-sedimentary sequence of metasediments, marbles, calc-silicate schists, and meta-igneous rocks of Permo-Carboniferous to latest Cretaceous ages that tectonically overlie Pre-Carboniferous schists and Carboniferous gneisses of the Cycladic basement [46,51]. The Cycladic blueschist unit underwent three stages of metamorphism during the Tertiary (e.g., [53]); the first, blueschist-to-eclogitefacies metamorphism, occurred during the Eocene ( $52-40 \mathrm{Ma})$ as a result of the Eocene subduction. A subsequent Eocene-Oligocene (ca. 40-30 Ma) upper greenschist-facies metamorphic event was linked to synorogenic exhumation. Finally, post-orogenic slab rollback during the Oligo-Miocene and back-arc extension led to 25-17 Ma greenschistto upper amphibolite-facies metamorphism followed by crustal anatexis at about $17 \mathrm{Ma}$ and exhumation of Attic-Cycladic metamorphic core complexes along a series of low-angle 
extensional detachment faults, such as the Northern and the Western Cycladic detachment systems [50,53-55]. The latter is exposed on Lavrion and Hymittos in Attica and on the neighboring Cycladic islands of Kea, Kythnos, and Serifos over a strike length of $>150 \mathrm{~km}$ (e.g., $[53,55,56])$ (Figure 1b). The extensional event persisted until the late Miocene and also allowed for various granitoids to be intruded throughout the Attic-Cycladic belt between 15 and $6 \mathrm{Ma}$ [57-59]. The Upper tectonic unit consists of various unmetamorphosed Upper Permian to Jurassic volcaniclastics, ophiolites, and carbonates, greenschist-facies rocks of Cretaceous to Tertiary age, and Late Cretaceous amphibolite-facies rocks and granitoids (e.g., [60]). This occurs in the hanging wall of crustal-scale detachment faults on the Cyclades [50,51,55] (Figure 1b).

\section{Geology of the Lavrion Area}

The Lavrion area, on the western boundary of the Attic-Cycladic crystalline belt, consists of three main tectonic units of alpine age: Kamariza (or Lower tectonic unit), Lavrion blueschist (or Middle tectonic unit) and Berzekos (or Upper tectonic unit) [10,34,52,61] (Figure 2). Both the Kamariza and the Lavrion units can be correlated with the Cycladic blueschist unit $[10,42,52,61]$. Three stages of deformation and metamorphism were identified within the rocks of the Lavrion area with (a) syn-orogenic burial during subduction, (b) syn-orogenic exhumation in the Oligocene through greenschist-facies conditions, and

(c) post-orogenic exhumation during the Miocene and related to movement along the detachment system [42,61,62].

The Kamariza unit contains two Late Triassic-Early Jurassic age marble layers, the Upper and the Lower marble (up to $500 \mathrm{~m}$ and $150 \mathrm{~m}$ thick, respectively), and the so-called Kamariza schists, which are up to $300 \mathrm{~m}$ thick, and include pods of intercalated marbles between the Lower and the Upper (locally folded) marbles [9] (Figures 2 and 3). This unit is characterized by syn-orogenic blueschist-facies metamorphism, overprinted by early Miocene greenschist-facies metamorphism during post-orogenic exhumation [61]. It remained ductile until the late Miocene, and, subsequently, the detachment transitioned to brittle deformation in the late Miocene $[10,11,61,63]$.

The Lavrion blueschist unit (Figures 2 and 3) is of Late Jurassic to Cretaceous age and structurally overlies the Kamariza unit. It consists of a discontinuous, locally brecciated marble (e.g., Pounta marble), the overlying Lavrion schists (100-250 m thick) with lenses of metabasic rocks (e.g., prasinites), and upper marbles [35,52,63,64]. It is characterized by initial Eocene blueschist-facies metamorphism, followed by Oligocene (from 32-23 Ma) greenschist-facies metamorphism during syn-orogenic exhumation, and evolved into brittle conditions by the middle Miocene ( 14 Ma), while the Kamariza unit was ductilely deforming [10,61,63].

The Berzekos unit (Upper tectonic unit) has limited exposure and consists of Upper Cretaceous non-metamorphic limestone, chert, and serpentinite up to $80 \mathrm{~m}$ thick (e.g., Berzekos area) [10,34].

At Lavrion, where the northwestern trace of the Western Cycladic detachment system (Figures 2 and 3) is exposed (e.g., [55]), the dominant structure is a ductile-to-brittle subhorizontal detachment zone, with mylonitic-to-ultramylonitic marbles and schists in the immediate footwall, structurally below a cataclastic fault that grades into schists and marbles of the hanging wall $[10,42,61]$ (Figure 3f,g). The detachment fault ranges from a few centimeters to tens of meters of mylonitic Upper Kamariza marble and an overlying cataclastic mélange (up to $4 \mathrm{~m}$ thick) composed of angular and rounded blocks at the interface of the marble and the overlying rocks of the Lavrion unit (Lavrion schists or Pounta marble) $[10,45]$. Early ductile deformation was overprinted by late-stage cataclastic deformation (e.g., brittle stage), which affected both the marble and the Kamariza schists. The Western Cycladic detachment system at Lavrion consists of two distinct branches, which separate the three tectonic units (Kamariza, Lavrion, and Berzekos). 

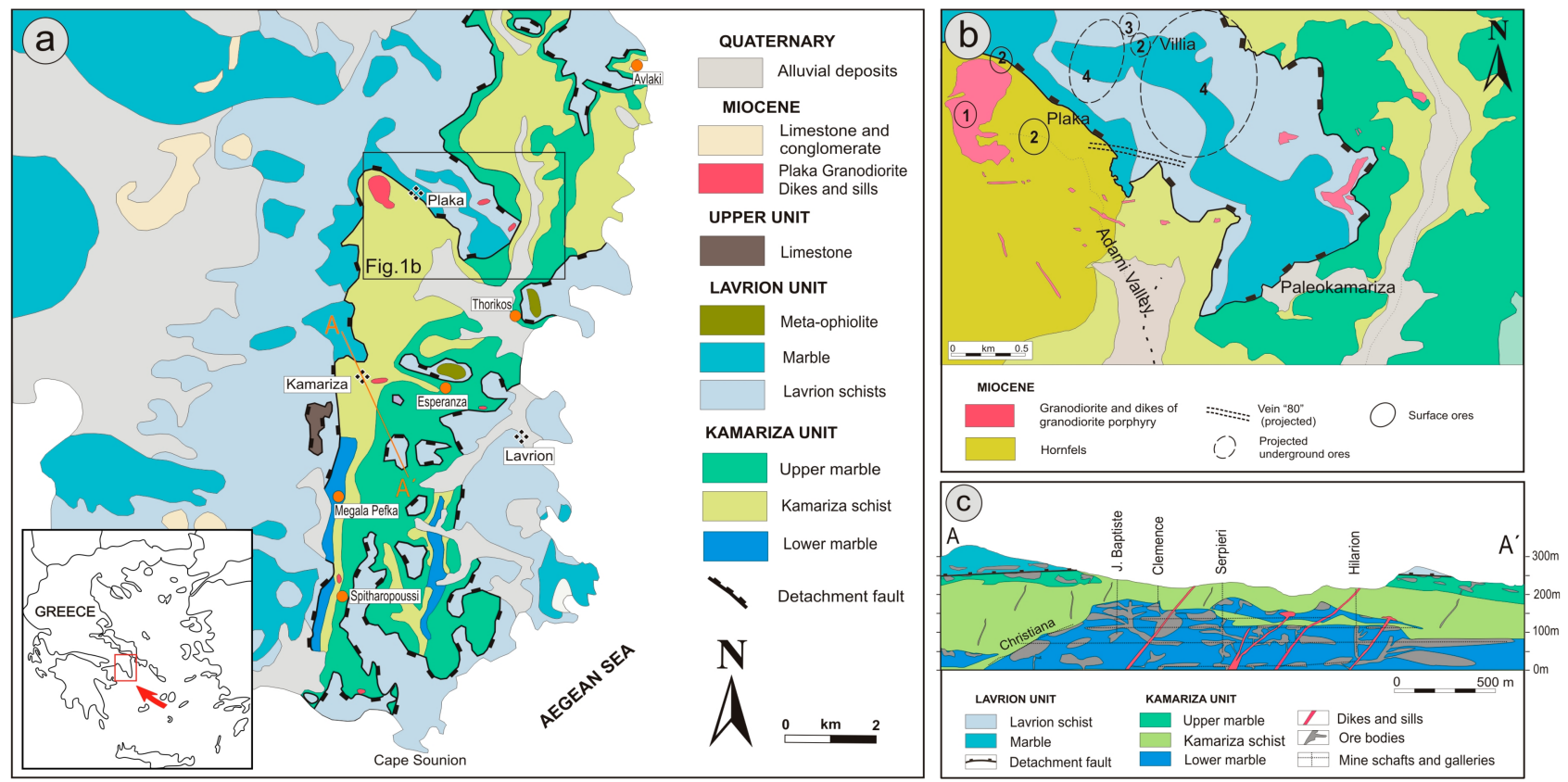

Figure 2. (a) Simplified geological map of the Lavrion ore district (from Marinos and Petraschek [9], Scheffer et al. [42] and modified after Voudouris et al. [37]); (b) geological sketch map of the Plaka area (modified after [37,66]). 1: porphyry-type mineralized granodiorite, 2: skarn-type mineralization, 3: breccia-type mineralization, 4: skarn-free carbonate replacement mineralization, 5: vein 80 mineralization; (c) cross-section A- $\mathrm{A}^{\prime}$ of the Kamariza deposit (see geological map, Figure 2a) (modified after Marinos and Petraschek [9], Ross et al. [19], Voudouris et al. [38]).

In the Plaka area, the footwall was intruded by a Late Miocene granodiorite stock [57] (Figures $2 \mathrm{~b}$ and $4 \mathrm{a}-\mathrm{c}$ ). The granodiorite has a medium-grained, equigranular texture and consists mainly of plagioclase, orthoclase, biotite, quartz, and hornblende. Several undeformed porphyry granodioritic and related dacitic dikes crosscut the metamorphic footwall rocks in the Plaka area, striking WNW-ESE to NE-SW. They are hydrothermally altered and locally mineralized [65] (Figure 4d,e).

In addition, deformed granitoids occur as sills and dikes situated along the detachment contact between the two lithologies or within the hanging wall, indicating that the intrusion of the magma took place at the ductile to brittle transition during emplacement of the Lavrion over the Kamariza unit rocks during the Middle to Upper Miocene $[62,66,67]$ (Figure 4f). Aeromagnetic data for the Lavrion district show the existence of a large batholith at depth in the Plaka area and that the dikes are apophyses from the central, large intrusion [68]. In the Kamariza area, east-trending mafic and acid dikes and sills (the so-called "evrites") dip towards the north and crosscut the Lower marble and the Kamariza schists (Figures 2c and 4g).

Based on their mineralogical composition and preliminary geochemical data, they are classified as microdiorites and microgranites, respectively [69]. According to Marinos and Petrascheck [9], the largest dikes in the Kamariza area outcrop north of the "Serpieri 1 " shaft, between the "Serpieri 1", the "Hilarion 1" shafts, and the south of the Hilarion orebody (Figure 2c).

The granodiorite and the dikes within the Kamariza and the Lavrion units are metaluminous to peraluminous and are classified as both I- and S-type granites $[40,65,67,69]$ (Figure 4). Radiometric dating performed on several granitoid rocks from the footwall and the hanging wall of the detachment fault in Lavrion area provide ages for the igneous activity at Lavrion between 9.4 to $7.3 \mathrm{Ma}[57,65,67]$. Ages between 7.9 and $7.1 \pm 0.6 \mathrm{Ma}$ indicate that mineralization and rapid cooling of the footwall through $\sim 180^{\circ} \mathrm{C}$ occurred at ca. 7.6 Ma [11]. An extensive contact metamorphic aureole (calc-silicate hornfels) occurs on the margin of the Plaka granodiorite intrusion along its contact with the Kamariza schists 
(Figures $2 \mathrm{~b}$ and $4 \mathrm{i}$ ) [70]. The hornfels comprises epidote, garnet, clinopyroxene, K-feldspar, plagioclase, chlorite, calcite, and quartz.
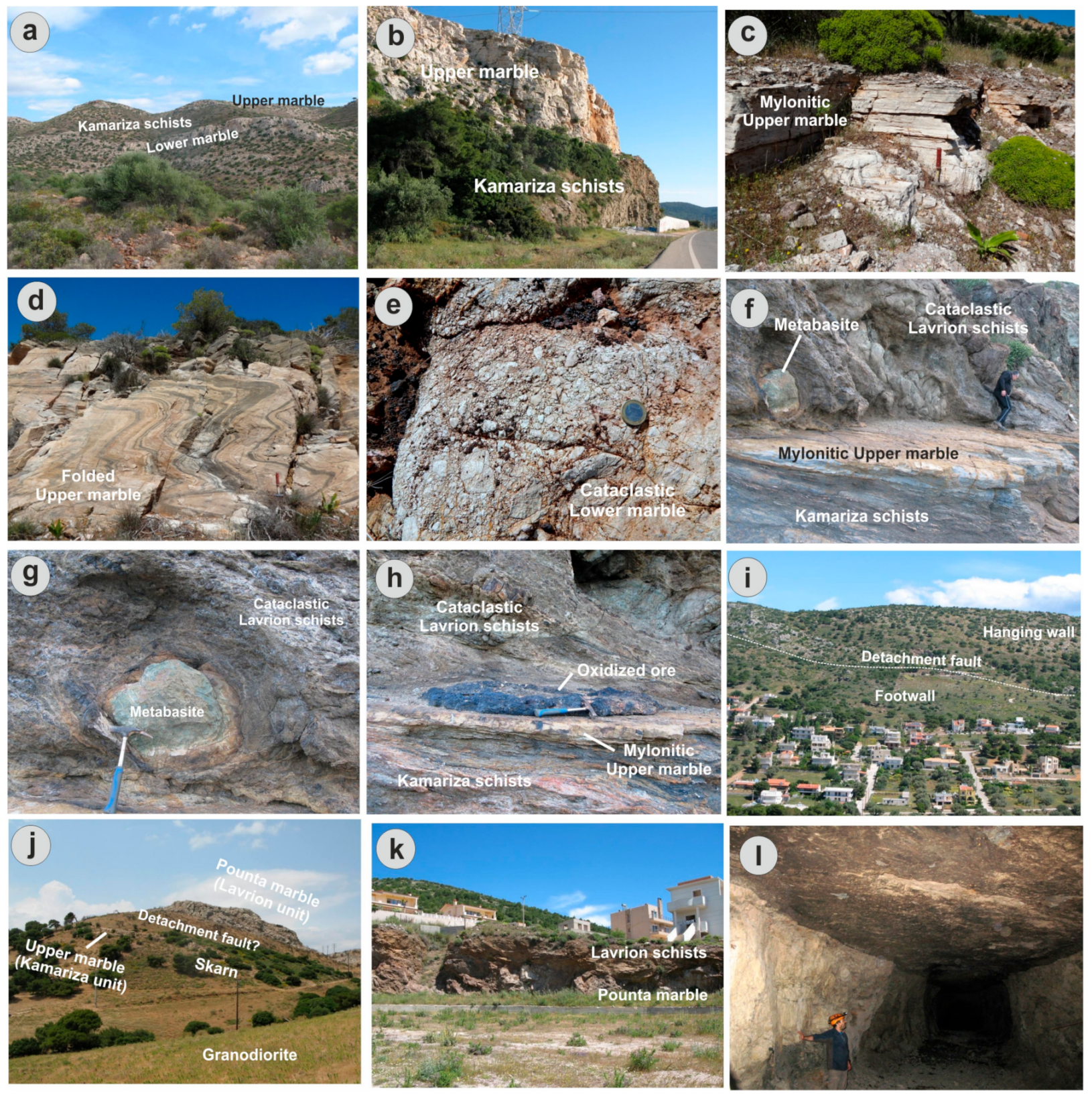

Figure 3. Field photos showing typical lithologies and tectonic features in the Lavrion area. (a) Geology of the Kamariza unit of Lavrion at Legrena Valley showing the superposition of Lower marble, Kamariza schists, and Upper marble; (b) Kamariza Unit: Upper marble overlying Kamariza schists; (c) Upper mylonitic white marble, "Km 3" locality; (d) deformed and folded Upper marble at Kamariza; (e) cataclastic Lower marble crosscut by iron oxides, marking the detachment at Legrena Valley below Spitharopoussi; (f-h) the West Cycladic detachment at Avlaki (Porto Enia), separating mylonitic footwall Upper marble and Kamariza schists from hanging wall Lavrion blueschist unit that is composed of cataclastic schists and metabasite bodies. Oxidized sulfide ore is syn-deformational. Metabasite within cataclastic mélange composed of subrounded fragments of Lavrion schists; (i) trace of the detachment fault, separating Upper marble of the Kamariza unit (footwall) from hanging wall rocks composed of marbles and schists of the Lavrion unit (Plaka village); (j) Lavrion unit (e.g., Pounta marble) superimposed on Kamariza unit (Upper marble) and skarnified Kamariza schists. Plaka granodiorite is also present; (k) Lavrion schists overlying Pounta marble at Plaka village; (1) underground exposure of the detachment fault surface separating Kamariza schists and granitoids from cataclastic Lavrion schists at Plaka, Villia mine no. “2033”. 

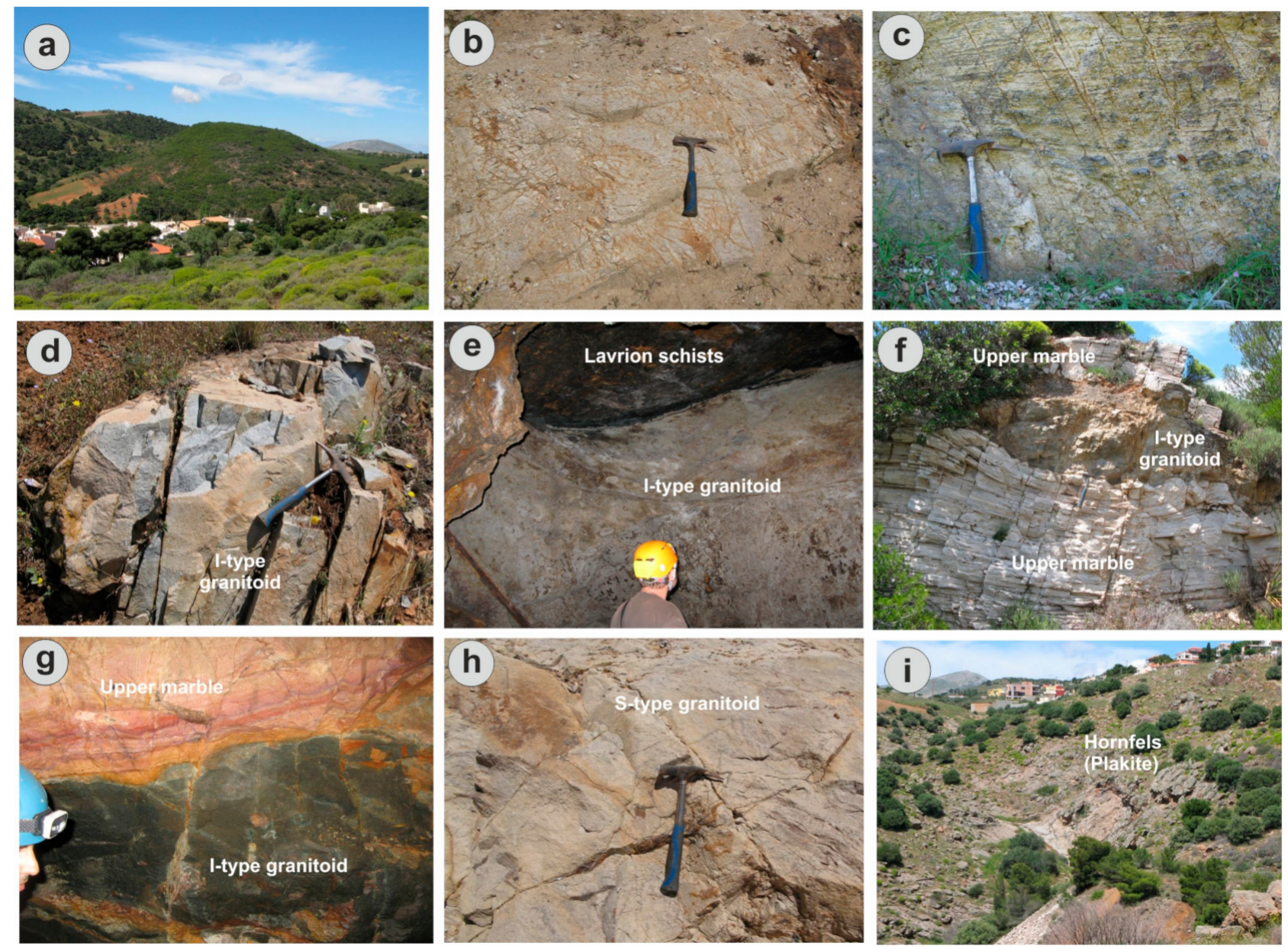

Figure 4. Field photos demonstrating various granitoid rock types in the Lavrion district. (a) View of "Granodiorite Hill" (also called "Porphyry Hill") close to Plaka village (from E to W); (b) Plaka granodiorite with iron oxide staining; (c) mylonitized Plaka granodiorite at "Granodiorite Hill"; (d) post-deformation I-type granitoid crosscutting hornfelses at Plaka; (e) I-type granitoid along the detachment fault, below Lavrion schists. Villia area; (f) deformed granitoid within mylonitized and fractured Upper marble at "Km 3" location; (g) propylitic and kaolinite-sericite altered microdiorite dike from the Jean Baptiste deposit, Kamariza area; (h) S-type granitoid sill (locally brecciated) within the hanging wall Lavrion unit at Paleokamariza; (i) hornfels in the Plaka area.

To summarize, the evolution of the Lavrion area can be resolved into a tectonic progression involving SSW-directed ductile to brittle extension, localized plutonism, and rapid cooling of the footwall of the Western Cycladic detachment system between 9 and $6 \mathrm{Ma}$. Thus, the detachment fault strongly influenced the location and the character of the mineralization at Lavrion.

\section{Types of Mineral Deposits}

The Lavrion district is unique in that five types of mineralization are spatially associated with each other over an area of approximately $150 \mathrm{~km}^{2}$ (Figures 2-4) $[37,38,40]$. These five types consist of (a) porphyry Mo-W, (b) Fe-Cu-Bi-Au skarn, (c) high-temperature carbonate replacement (skarn-free) $\mathrm{Pb}-\mathrm{Zn}-\mathrm{Cu}-\mathrm{Ag}$-Au mineralization, and (d,e) Pb-Zn-Ag$\mathrm{Au}$ vein and breccia. These types of mineralization occur in close proximity to and/or superimposed on each other in the Plaka area, where they are spatially associated with the Plaka granodiorite and related dikes. They also occur elsewhere in the Lavrion district, at, for example, the Serpieri mine in the Kamariza area.

Primary ore mineralization at Lavrion consists of an enormous number of metallic minerals, among them sulfides and sulfoarsenides (pyrite, arsenopyrite, chalcopyrite, 
galena, sphalerite, gersdorffite, marcasite), native metals (Au and Bi), Sn-In-bearing sulfosalts (petrukite, stannite, roquesite), and various sulfosalts of $\mathrm{Ag}, \mathrm{Bi}, \mathrm{Cu}, \mathrm{Pb}, \mathrm{As}$, and $\mathrm{Sb}$ (tetrahedrite-group minerals, bournonite, boulangerite, stephanite, baumstarkite, fizélyite, freieslebenite, pyrargyrite, proustite, semseyite, plagionite, enargite, famatinite, bismuthinite, lillianite homologues, matildite, aikinite, mummeite, emplectite, wittichenite) [71-75]. The accumulation and the abundance of 49 elements, mainly various chalcophile metals, played a major role in the formation of an enormous variety of late supergene minerals in the oxidation zone.

The ore deposits in Lavrion are both structurally and lithologically controlled, and ore formation occurred under extensional kinematic conditions [11,36-38,40,43,44]. The most important ore bodies exploited by the ancient miners are along the so-called third and first contact (i.e., between the Lower Kamariza marble and the Kamariza schist and between the Upper Kamariza marble and the detachment fault, respectively) [13,14]. Ross et al. [45] reassessed the character of the mineralization mined by the ancient Greeks and indicated that production from exposed and shallow first contact mineralization began in the fourth millennium BC and continued until the first millennium BC and was based on widely dispersed, thin, irregular, oxidized, and lower grade deposits. In contrast, the discovery of third contact mineralization at $483 \mathrm{BC}$ resulted in production from thick, continuous, and higher grade deposits and focused around the Kamariza area. Mineralization also occurs both above the main detachment (e.g., within Lavrion schists and Pounta marbles) and below the detachment (e.g., within the Lower Kamariza marble, the Kamariza schist, within the Upper Kamariza marble, and at its lower contact with Kamariza schist).

\subsection{Porphyry Type}

An intrusion-hosted Mo $( \pm \mathrm{W})$ mineralization, with surface dimensions of about $400 \times 300 \mathrm{~m}^{2}$, occurs as sheeted quartz veins and stockworks crosscutting the Plaka granodiorite (Figures $2 b$ and $5 a, b)[37,40]$. The quartz veins consist mainly of granular medium-grained quartz and hydrothermal biotite. The sheeted veins strike generally NWSE and are up to $40 \mathrm{~cm}$ wide. The Plaka granodiorite was intensely altered by hydrothermal fluids, producing five types of alteration (potassic, sodic-calcic, propylitic, sericitic, and silicic). The primary mineralization consists of pyrite, molybdenite, chalcopyrite, pyrrhotite, and scheelite, with accessory monazite-(Ce), xenotime-(Y), zircon, thorite, rutile, and late-hydrothermally formed members of the alunite supergroup [37,73]. Porphyry-type mineralization also occurs in the Serpieri deposit at Kamariza (operated during the modern mining era at Lavrion), where microgranite dikes are crosscut by stockworks hosting pyrrhotite, arsenopyrite, pyrite, and galena. The veinlets are related to carbonate-sericite alteration of the host rock, which overprints secondary biotite and K-feldspar, being part of an earlier potassic alteration event [69].

\subsection{Skarn-Type}

Early hornfels formation was followed by the multistage development of a $\mathrm{Cu}$-Fe skarn deposit around the Plaka granodiorite, which is hosted mainly within the Kamariza schists and the Lower and the Upper marbles $[32,33,37]$ (Figures $2 b, 3 \mathrm{~h}$ and $5 c, d$ ). In the skarn type of mineralization, early magnetite was followed by pyrrhotite, pyrite, arsenopyrite, sphalerite, chalcopyrite, and Bi-Ag-rich galena. Bismuth-, tellurium-, and gold-bearing ores were also described by Leleu et al. [32], Kolitsch et al. [73], and Rieck et al. [75]. Magnetitepyrrhotite-pyrite ore is accompanied by clinopyroxene, amphibole, garnet (andraditegrossular), quartz, chlorite, and epidote. According to Bonsall et al. [40], the skarn-related metallic content changes with the proximity to the Plaka granodiorite; magnetite and magnetite-hematite are closer to the granodiorite in the Upper marbles, while the assemblages pyrite-pyrrhotite and sphalerite-pyrite-galena occur in the Kamariza schists, farther away from the granodiorite. 

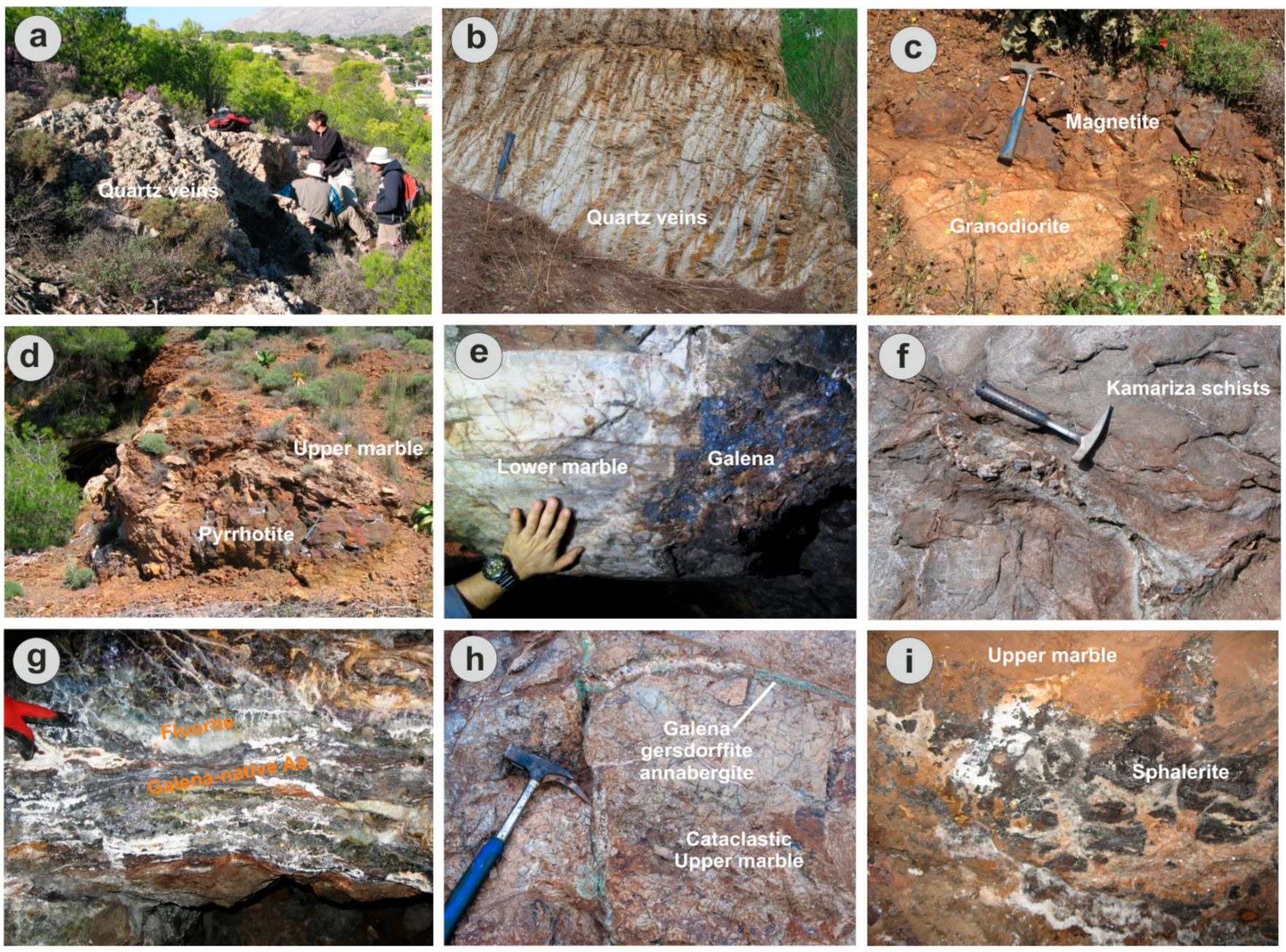

Figure 5. Field photos showing various mineralization styles at Lavrion. (a) Quartz veinlets hosting porphyry-style molybdenite mineralization on top of "Granodiorite Hill" at Plaka; (b) quartz stockworks and sheeted veins with oxidized porphyry-type mineralization crosscutting potassic-altered Plaka granodiorite; (c) skarn mineralization with magnetite surrounding granodiorite; (d) massive pyrrhotite in skarn mineralization within the Upper marble, Plaka village; (e) massive carbonate-replacement galena ore within the Lower marble, Jean Baptiste mine (Kamariza area); (f) vein-type galena-quartz mineralization crosscutting Kamariza schists at Avlaki (Porto Ennia); (g) Vein 80 from Plaka showing alternating bands of galena, native arsenic, and fluorite; (h) galena-gersdorffite veins crosscutting brecciated Upper marble at the annabergite "Km 3" location; (i) breccia-type sphalerite-rich mineralization within Upper marble at Esperanza mine (Kamariza area).

A minor skarn occurrence is located along the contact of the above-mentioned microgranite body and the Lower marble at the Serpieri mine [69]. It is a garnet-rich skarn, with andradite, wollastonite, apatite, and magnetite being part of the prograde mineral assemblage. Calcite, actinolite, epidote, chlorite, quartz, and hematite, as well as pyrite, chalcopyrite, and pyrrhotite formed during the retrograde stage [69].

\subsection{Carbonate-Replacement Mineralization}

The carbonate-replacement $\mathrm{Pb}-\mathrm{Zn}-\mathrm{Cu}-\mathrm{Ag}$ - $\mathrm{Au}$ mineralization is among the most economically important in Lavrion district. It occurs in the form of stratabound lenses to bedded replacement (mantos) and chimneys (crosscutting with respect to layering in the host marble), up to tens of meters in length, with the largest occurrences located in the Kamariza mining district (including Hilarion, Clemence, Jean Baptiste, Serpieri, and Christiana mines), the Plaka-Villia district, and in several other localities [9,36-38,43,44,71] (Figure $2 b, c$ and Figure 5e). This type of mineralization occurs mainly in the Kamariza unit marbles and in marbles within the Lavrion blueschist unit. The mineralization is 
dominated by pyrite, sphalerite, chalcopyrite, and galena (Figure 5e). Quartz, fluorite, and calcite are the gangue minerals (Figure 5). Alteration around the orebodies consists of hydrothermal dolomite, calcite, siderite, ankerite, quartz, and sericite. The ore deposition took place mainly from high-T magmatic fluids during the transitional ductile/brittle and brittle deformation stage of the host rocks. In the carbonate-replacement mineralization, the dominant Ag-bearing phases are sulfosalts of Bi and Ag- and Bi-rich galena.

\section{4. $\mathrm{Pb}-\mathrm{Zn}-\mathrm{Ag}-\mathrm{Au}$ Epithermal Veins and Breccias}

In addition to the carbonate-replacement mineralization, the vein- and the breccia $\mathrm{Pb}-$ $\mathrm{Zn}$-Ag-Au ores (Figures $2 \mathrm{~b}$ and $5 \mathrm{f}-\mathrm{i}$ ) were of major economic importance to Lavrion. Veinand breccia-type mineralization occurs at several places such as in Thorikos, Kamariza, Spitharopoussi, Ari, and Megala Pefka as well as in "Km 3", Esperanza, Sounio, and Avlaki locations, whereas the largest vein, which is known as "Vein 80", occurs at Plaka, crosscutting the contact metamorphic aurole of the local granodiorite $[37,38,43,44] . \mathrm{Pb}-$ $\mathrm{Zn}$-Ag vein and breccia deposits are generally localized below, but they also occur above the Lavrion detachment within the marbles of the Lavrion unit, the Upper marble, the Kamariza schists, and at the interface between the Kamariza schists and the Lower marble. The vein- and the breccia-type deposits were formed as the rock entered the brittle regime, by mixed seawater and meteoric fluids $[11,40,43,44]$. The deposits are mainly characterized by fluorite and carbonate gangue minerals enclosing $\mathrm{Pb}-\mathrm{Zn}-\mathrm{Ag}$ sulfides and/or oxides. Vein 80 is located $800 \mathrm{~m}$ to the east of the Plaka granodiorite (Figure 2b). It consists of an up to $2 \mathrm{~m}$ thick and up to $1 \mathrm{~km}$ long sub-horizontal vein system, oriented ESE-WNW. Vein 80 is a $\mathrm{Pb}-\mathrm{As}-\mathrm{Sb}-\mathrm{Cu}-\mathrm{Ag}$ rich system that crosscuts hornfels, mylonitic, and cataclastic marbles, the detachment fault, and carbonate replacement mineralization. Silver in galena from vein- and breccia-types of mineralization is associated with sub-microscopic inclusions of various Ag-sulfosalts, such as, among others, pyrargyrite, proustite, stephanite, ramdohrite, fizélyite, freieslebenite, marrite, and Ag-rich members of the tetrahedrite group. Vein-type $\mathrm{Pb}-\mathrm{Ni}$-Bi-Au-Ag mineralization at the Clemence deposit in the Kamariza district contains extremely high gold grades (e.g., >100 g/t), with native gold associated with bismuthinite, gersdorffite, and galena [69].

\section{Lavrion Primary and Supergene Minerals}

The Lavrion area contains 638 primary and supergene minerals (e.g., more than 12\% of all known minerals worldwide), of which 23 were first found in Lavrion (type-locality minerals) [1,2,5,12,71-101] (Table 1). The extended and ongoing oxidation of the primary ore resulted in the formation of one of the best developed oxidation zones on Earth (up to $270 \mathrm{~m}$ thick), with the lowest mine levels being partly below the present (slightly saline) groundwater table $[9,39]$ (Figure 6a,b).

The polymetallic sulfide mineralization of Lavrion (mainly pyrite, chalcopyrite, galena, and sphalerite, which accompany quartz, fluorite, and calcite as gangue minerals) (Figure 6c-e) was subjected to supergene oxidation that formed a gossan. This process involved downwardpenetrating water, oxidation of hypogene sulfides, partial mobilization of elements, and their re-precipitation in open spaces developed by interaction of acidic water with marble. Surface exposure of the Lavrion stratigraphy is believed to have occurred about $5 \mathrm{Ma}$ ago, following tectonic uplift in association with variations in paleoclimate in the last $5 \mathrm{Ma}$. This resulted in supergene oxidation of near-surface mineralization [45]. Furthermore, in the last million years, oxidation processes have been amplified by several fluctuations of up to $120 \mathrm{~m}$ in sea level, which lowered the water table and deepened oxidation to far below current levels [45].

During the supergene oxidation, pyrite $\left(\mathrm{FeS}_{2}\right)$ was altered to goethite $(\mathrm{FeO}(\mathrm{OH}))$, which then dehydrated to hematite $\left(\mathrm{Fe}_{2} \mathrm{O}_{3}\right)$; galena $(\mathrm{PbS})$ was replaced by cerussite $\left(\mathrm{PbCO}_{3}\right)$ and anglesite $\left(\mathrm{PbSO}_{4}\right)$, whilst alteration of sphalerite $(\mathrm{ZnS})$ led to precipitation of smithsonite $\left(\mathrm{ZnCO}_{3}\right)$, hydrozincite $\left(\mathrm{Zn}_{5}\left(\mathrm{CO}_{3}\right)_{2}(\mathrm{OH})_{6}\right)$, and hemimorphite $\left(\mathrm{Zn}_{4}\left(\mathrm{Si}_{2} \mathrm{O}_{7}\right)(\mathrm{OH})_{2} \mathrm{H}_{2} \mathrm{O}\right)[48]$. Chalcopyrite altered to secondary $\mathrm{Cu}$ minerals, including malachite $\left(\mathrm{CuCO}_{3} \mathrm{Cu}(\mathrm{OH})_{2}\right)$, azurite $\left(\left(\mathrm{CuCO}_{3}\right)_{2} \mathrm{Cu}(\mathrm{OH})_{2}\right)$, brochantite $\left(\mathrm{Cu}_{4}\left(\mathrm{SO}_{4}\right)(\mathrm{OH})_{6}\right)$, antlerite $\left(\mathrm{Cu}_{3}\left(\mathrm{SO}_{4}\right)(\mathrm{OH})_{4}\right)$, ata- 
camite $\left(\mathrm{Cu}_{2}(\mathrm{OH})_{3} \mathrm{Cl}\right)$, cuprite $\left(\mathrm{Cu}_{2} \mathrm{O}\right)$, and native $\mathrm{Cu}$. Some other secondary minerals in the gossan are jarosite, natrojarosite, plumbojarosite, wulfenite, mimetite, adamite, annabergite, gypsum, scorodite, covellite, beudantite, olivenite, hetaerolite, hydrohetaerolite, aragonite, ankerite, ktenasite, cyanotrichite, chalcanthite, chrysocolla, and beudantite (Figure 6). Minerals formed at the expense of pyrrhotite, pyrite, and chalcopyrite are widespread and consist of efflorescent salts (e.g., halotrichite, melanterite, rozenite, fibroferrite, römerite, voltaite, and copiapite-group minerals) $[74,75,87]$. Twenty-three minerals were first reported from Lavrion mines (e.g., attikaite, glaucocerinite, ktenasite, kapellasite, hilarionite, zinkolivenite, agardite-(Nd), nickeltsumcorite, kamarizaite and serpierite and several Cd-Zn-bearing sulfates as niedermayrite, lazaridisite, voudourisite, drobecite, and katerinopoulosite from the Esperanza mine $[82,87,88,91,95])$ (Table 1).

Table 1. List of the 23 type locality (TL) minerals from Lavrion area (data from mindat.org page of Branko Rieckhttps:/ /www.mindat.org/loc-1942.html, and related articles).

\begin{tabular}{|c|c|c|c|}
\hline Mineral & Formula & Location/Mine & Ref. \\
\hline Agardite-(Nd) & $\mathrm{NdCu}_{6}\left(\mathrm{AsO}_{4}\right)_{3}(\mathrm{OH})_{6} \bullet 3 \mathrm{H}_{2} \mathrm{O}$ & Hilarion 50 & {$[80]$} \\
\hline Attikaite & $\mathrm{Ca}_{3} \mathrm{Cu}_{2} \mathrm{Al}_{2}\left(\mathrm{AsO}_{4}\right)_{4}(\mathrm{OH})_{4} \cdot 2 \mathrm{H}_{2} \mathrm{O}$ & Christiana 132 & [81] \\
\hline Drobecite & $\mathrm{CdSO}_{4} \bullet 4 \mathrm{H}_{2} \mathrm{O}$ & Esperanza & [82] \\
\hline Glaucocerinite & $\left(\mathrm{Zn}_{1-\mathrm{x}} \mathrm{Al}_{\mathrm{x}}\right)(\mathrm{OH})_{2}(\mathrm{SO} 4)_{\mathrm{x} / 2} \bullet \mathrm{nH}_{2} \mathrm{O}$ & Serpieri & [83] \\
\hline Hilarionite & $\mathrm{Fe}^{3+}{ }_{2}\left(\mathrm{SO}_{4}\right)\left(\mathrm{AsO}_{4}\right)(\mathrm{OH}) \bullet 6 \mathrm{H}_{2} \mathrm{O}$ & Hilarion 50 & {$[84]$} \\
\hline Kamarizaite & $\mathrm{Fe}^{3+}{ }_{3}\left(\mathrm{AsO}_{4}\right)_{2}(\mathrm{OH})_{3} \bullet 3 \mathrm{H}_{2} \mathrm{O}$ & Kamariza & [85] \\
\hline Kapellasite & $\mathrm{Cu}_{3} \mathrm{Zn}(\mathrm{OH})_{6} \mathrm{Cl}_{2}$ & Sounion 19 & [86] \\
\hline Katerinopoulosite & $\left(\mathrm{NH}_{4}\right)_{2} \mathrm{Zn}\left(\mathrm{SO}_{4}\right)_{2} \bullet 6 \mathrm{H}_{2} \mathrm{O}$ & Esperanza & [87] \\
\hline Katsarosite & $\mathrm{Zn}\left(\mathrm{C}_{2} \mathrm{O}_{4}\right) \cdot 2 \mathrm{H}_{2} \mathrm{O}$ & Esperanza & {$[88]$} \\
\hline Ktenasite & $\mathrm{ZnCu}_{4}\left(\mathrm{SO}_{4}\right)_{2}(\mathrm{OH})_{6} \bullet 6 \mathrm{H}_{2} \mathrm{O}$ & Jean Baptiste & [89] \\
\hline Laurionite & $\mathrm{PbCl}(\mathrm{OH})$ & Kamariza & [90] \\
\hline Lazaridisite & $\mathrm{Cd}_{3}\left(\mathrm{SO}_{4}\right)_{3} \bullet 8 \mathrm{H}_{2} \mathrm{O}$ & Esperanza & [91] \\
\hline Mereiterite & $\mathrm{K}_{2} \mathrm{Fe}\left[\mathrm{SO}_{4}\right]_{2} \bullet 4 \mathrm{H}_{2} \mathrm{O}$ & Hilarion 50 & {$[92]$} \\
\hline Natroglaucocerinite & {$\left[\mathrm{Zn}_{5} \mathrm{Al}_{3}(\mathrm{OH})_{16}\right]\left[\left(\mathrm{SO}_{4}\right)_{1.5} \mathrm{Na}_{1.5}\left(\mathrm{SO}_{4}\right)_{0.75}\left(\mathrm{H}_{2} \mathrm{O}\right)_{9}\right]$} & Hilarion & [93] \\
\hline Nickeltsumcorite & $\mathrm{Pb}\left(\mathrm{Ni}, \mathrm{Fe}^{3+}\right)_{2}\left(\mathrm{AsO}_{4}\right)_{2}\left(\mathrm{H}_{2} \mathrm{O}, \mathrm{OH}\right)_{2}$ & “Km 3" & [94] \\
\hline Niedermayrite & $\mathrm{CdCu}_{4}\left(\mathrm{SO}_{4}\right)_{2}(\mathrm{OH})_{6} \bullet 4 \mathrm{H}_{2} \mathrm{O}$ & Esperanza & [95] \\
\hline Prachařite & $\mathrm{CaSb}^{5+}{ }_{2}\left(\mathrm{As}^{3+}{ }_{2} \mathrm{O}_{5}\right)_{2} \mathrm{O}_{2} \bullet 10 \mathrm{H}_{2} \mathrm{O}$ & Plaka 80 & {$[96]$} \\
\hline Serpierite & $\mathrm{Ca}(\mathrm{Cu}, \mathrm{Zn})_{4}\left(\mathrm{SO}_{4}\right)_{2}(\mathrm{OH})_{6} \bullet 3 \mathrm{H}_{2} \mathrm{O}$ & Serpieri & [97] \\
\hline Stergiouite & $\mathrm{CaZn}_{2}\left(\mathrm{AsO}_{4}\right)_{2} \bullet 4 \mathrm{H}_{2} \mathrm{O}$ & Plaka 80 & [98] \\
\hline Voudourisite & $\mathrm{Cd}\left(\mathrm{SO}_{4}\right) \bullet \mathrm{H}_{2} \mathrm{O}$ & Esperanza & {$[91]$} \\
\hline Zincaluminite & $\mathrm{Zn}_{6} \mathrm{Al}_{6}\left(\mathrm{SO}_{4}\right)_{2}(\mathrm{OH})_{16} \cdot 5 \mathrm{H}_{2} \mathrm{O}$ & Hilarion & [99] \\
\hline Zincolivenite & $\mathrm{CuZn}\left(\mathrm{AsO}_{4}\right)(\mathrm{OH})$ & Kamariza & [100] \\
\hline Zincowoodwardite & {$\left[\mathrm{Zn}_{1-\mathrm{x}} \mathrm{Alx}(\mathrm{OH})_{2}\right]\left[\left(\mathrm{SO}_{4}\right)_{\mathrm{x} / 2} \bullet \mathrm{n}\left(\mathrm{H}_{2} \mathrm{O}\right)\right]$} & Christiana & [101] \\
\hline
\end{tabular}

Others were first discovered in antique Lavrion slags where they formed by interaction with seawater (e.g., fiedlerite, thorikosite, georgiadesite, nealite, paralaurionite, and penfieldite) [102-110]. These so-called slag minerals are formed in sites where metallurgical wastes occur and represent the products of recent re-distribution of metals and subsequent precipitation in the form of oxides, hydroxides, or salts.

Silver in galena occurs as inclusions of various Ag sulfosalts and in solid solution [37,38,40]. However, when galena was oxidized to cerussite and anglesite, Ag was mobilized, and the resulting secondary $\mathrm{Ag}$ was precipitated as the low-temperature sulfide acanthite $\left(\mathrm{Ag}_{2} \mathrm{~S}\right)$, chlorargyrite $(\mathrm{AgCl})$, and as native $\mathrm{Ag}$ mostly as inclusions in cerussite [2,5,12,44,45,111]. Cerussite in addition to galena is a major carrier of silver in the Lavrion deposit. 

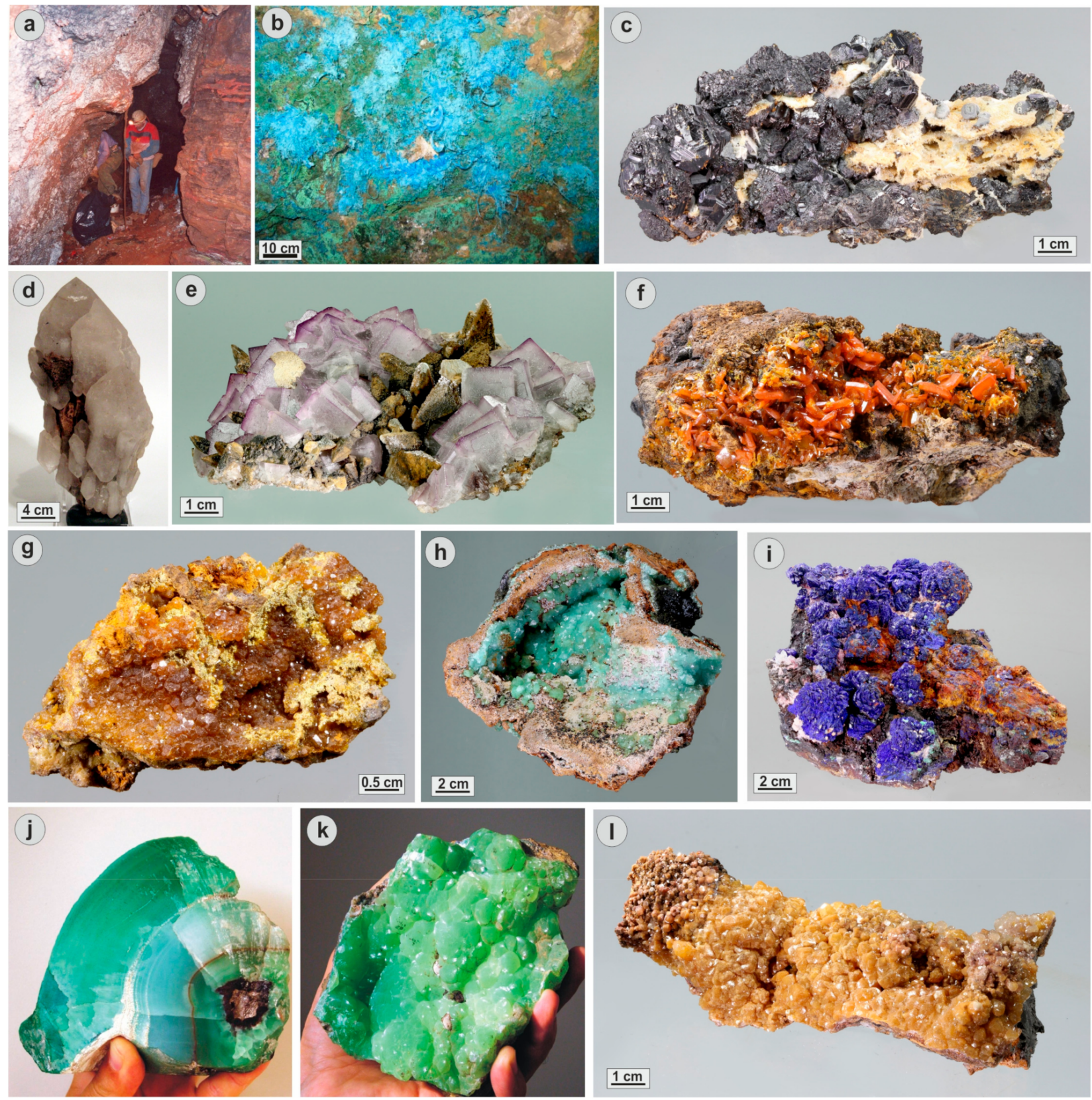

Figure 6. Supergene oxidation, secondary (and primary) minerals at Lavrion. (a) Oxidized Lower marble at the mixite location, Hilarion mine, Kamariza; (b) chalcanthite formed after chalcopyrite and pyrite at Hilarion mine, Kamariza; (c) sphalerite, galena, and quartz from the Mine 9, Avlaki area; (d) quartz from Christiana mine, Kamariza; (e) fluorite and calcite from Megala Pefka mine; (f) wulfenite from Adami mine, Plaka area; (g) mimetite from Adami mine, Plaka area; (h) Cu-bearing adamite, as pseudo-octahedral crystals, Hilarion mine, Kamariza; (i) azurite from Christiana mine, Kamariza; (j,k) Cu-bearing smithsonite from Hilarion mine, Kamariza; (1) smithsonite from Jean Baptiste mine, Kamariza. Photos (c,e, $\mathbf{f}, \mathbf{g}, \mathbf{h}, \mathbf{i}, \mathbf{l})$ are courtesy of B. Ottens (collection P. Voudouris). Photos (j,, $\mathbf{k})$ are from Voudouris et al. [4].

\section{Unique Mining and Metallurgical Features}

The Lavrion district is one of the oldest mining districts in the world, with evidence of early mining from the Late Neolithic period over 5000 years ago (Figure 7). Archaeological data including pottery and stone hammers point towards an early date for the first phase of mining in the Final Neolithic/Early Helladic period, c. 3200 BC [17]. Combined with its proven 5000 years of intermittent mining activity and the historical significance of the deposits, there is no comparable place in this world. Even the law governing mining 
throughout the civilized world has its roots in the set of rules formulated to organize the silver extraction from the Lavrion mining district. The extraordinary high silver grades of the ore coupled with cheap slave labor were directly responsible for the rise of the Athenian empire in antiquity. Undoubtedly, it is no coincidence that the flourishing of Athens in the Classical period and the democratic practices that accompanied it also coincided with increasing exploitation of rich silver mineralization at Lavrion. The archeological sites in the Lavrion mining area are extraordinary, with the world-famous Temple of Poseidon sitting above underground workings. This is already a very popular tourist destination, especially given its close proximity to Athens. Moreover, there are some spectacularly preserved ancient ore washing sites, locations for refining the ore into ingots, and entrances (adits, shafts) to old mines (Figure 7). The area is a unique conservatory of mining, ore-dressing, and metallurgical technologies that innovatively transformed the ore into metal.
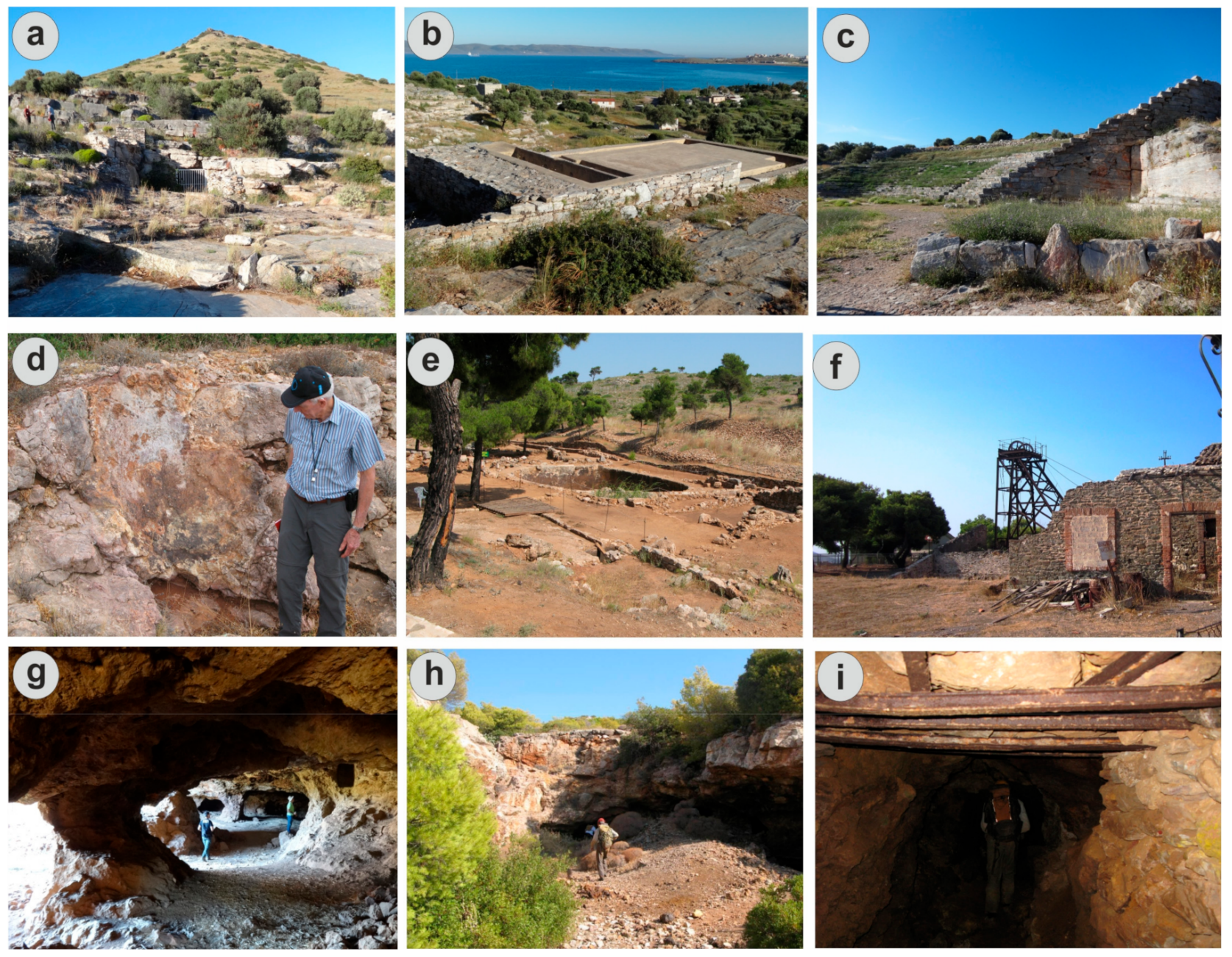

Figure 7. Field und underground photos showing evidence of ancient and modern mining activity, ore dressing, and metallurgical facilities at Lavrion. (a) Entrance of the prehistoric mine No 3 at Thorikos, within mylonitic Upper marble. On top, the Velatouri Hill comprising rocks of the Lavrion unit; (b) restoration of ancient ore washeries at Thorikos; (c) ancient Thorikos theater constructed within the Upper Kamariza marble; (d) ancient lead smelting furnace at Pounta Zeza; (e) ancient cisterns and ore dressing facilities at Soureza valley; (f) Serpieri shaft at Kamariza (Agios Konstantinos village); (g) ancient and modern galleries at "Km 3" location; (h) entrance of Esperanza mine within the Upper Kamariza marble; (i) modern galleries within oxidized ore in the Kamariza area.

Since prehistoric times, there has been an explosion of mining activity at Lavrion. Accordingly, this district represents a complex and unique technological system for leadsilver ore processing. White metal has become a real source of power but also a real 
source of inspiration for mining technologies. Its famous deep winding shafts explore underground space in a vertical plan and constitute the essential tools to mine the ore and the main access way to potential deeper mining levels. The sinking through particularly hard rock and the equipment used were innovative during ancient times.

The Lavrion lead-silver mines are the only ones known from the ancient world where vertical shafts that reached a depth of $100 \mathrm{~m}$ connect an underground network of galleries to exploit ore deposits [18]. These mines required sophisticated organizational, engineering, and technological capabilities and an excellent understanding of geology.

The underground environment is an overwhelming sanctuary where ancient mining activities are well preserved. Tool marks, printed fleeting traces abandoned on the floor, and fossilized foot prints of ancient miners are preserved in the rock or in waste materials that contain a considerable amount of information and evidence of ancient to recent mining activity. On the surface, remnant of ore dressing are well preserved. Ore-processing workshops at Lavrion played an important part in the production of silver during the classical times [112]. Workers processed the ores in specially designed workshops (e.g., washeries, cisterns, grinding stations) where they were crushed, ground, washed, and concentrated before being sent to the furnaces for smelting. Metallurgical workshop for the cupellation of argentiferous lead and archaeometallurgical residues (e.g., slags, furnace fragments, litharge) suggestive of smelting of ores or cupellation of lead are widespread [14,113]. Recent investigations and dating at Thorikos suggest exploitation of ore resources also during the Late Roman period, particularly in the fourth and the sixth centuries $\mathrm{AD}$, using fire setting technology [17].

According to Ross et al. [45], the contrasting character of mineralization at the first and the third contacts influenced exploitation and processing methods during the Lavrion mining history. Early (i.e., from the fourth to the first millennium BC) small-scale and individual surface mining and processing focused on $\mathrm{Ag}, \mathrm{Pb}, \mathrm{Fe}$, and $\mathrm{Cu}$ on strongly oxidized mineralization associated with the first contact. Lead and silver were produced during cupellation of either galena or its oxidation product, cerussite $[14,20]$. Abundant secondary $\mathrm{Cu}$-bearing minerals led to significant production of $\mathrm{Cu}$ at Lavrion during the first 3000 years [114]. The discovery of higher grade, third contact mineralization around Kamariza area, dated at $483 \mathrm{BC}$, marked a change on the mining history of Lavrion. It favored more continuous and large scale mining and processing operations [45].

Modern metallurgy and mining at Lavrion started at 1864 with the exploitation and the resmelting of the ancient slag heaps $[14,115]$. The two mining companies, "The Metallurgical Company of Lavrio" (1873-1927) and the "French Mining Company of Lavrio" (1875-1981, FMCL), operated mainly in Kamariza (e.g., the Hilarion, Clemence, Jean Baptiste, Serpieri and Christiana mines) and the Plaka-Villia districts and installed a full metallurgical complex that included roasting ores containing sulfur enrichments, making bricks of finely granulated rich ores and reduction smelting [115]. The old Castiliano-type furnaces were replaced by larger furnaces of the water jacket type; however, the technology of reduction smelting was very similar to that of the ancient techniques [115].

\section{Discussion}

\subsection{Educational and Research Activities}

From a geological point of view, the Lavrion area offers an excellent opportunity to study the interplay between (a) large-scale tectonic processes which took place during earlier Alpine collision and compression, followed by Miocene extension in the back-arc region of the Hellenic subduction zone; (b) magmatic activity, expressed by emplacement of various igneous rocks in a syn- to post-tectonic regime; (c) hydrothermal activity and fluid circulation within various lithologies, resulting in enormous quantities of ore deposition and related base and precious metal mineralization; (d) later supergene-weathering processes, resulting in a unique zone of supergene ore oxidation, which contains, in addition to the primary ores, the most mineral species ever found in a single mining district on 
Earth; and (e) the way geological processes have profoundly influenced ore deposition and the course of human history and technology.

The opportunities for the further development of education and research are emphasized below. What must be highlighted is the major contribution that Lavrion can offer by way of a large variety of educational activities. The characteristics of geological, mineralogical, and ore-forming processes and conditions in the individual locations are obvious and available at every visiting site and can become an educational case.

For educational purposes, teaching the Lavrion geology, mineralogy, and ore deposit formation is among the most favored subjects for students at several Greek universities (Figure 8). Several field trips take place every year in the Lavrion district as part of undergraduate and postgraduate courses. Moreover, through the supervision of several Bachelor, Master, and $\mathrm{PhD}$ theses, research on the Lavrion deposit has greatly improved our knowledge of the geological and the archaeological constraints that have affected the district. Over the last three decades, the National and Kapodistrian University of Athens, and especially the Faculty of Geology and Geoenvironment, organized several workshops and field trips for students and academics from all over the world at Lavrion and provided education content to students at the various levels (undergraduate, postgraduate, etc.) as well as for the broad public and professionals (Figure 8). Through collaboration with several universities and research institutions from all over the world, our scientific knowledge in the field of mineralogy, geology, mining, mineralizing, and supergene processes as well as in environmental and pollution processes (involving the toxic elements $\mathrm{Pb}, \mathrm{As}, \mathrm{Cd}$, and others) has greatly improved. Lavrion has attracted a large number of researchers working on geology, metallogeny, and mineralogy but also on archaeology and archaeometallurgy.

Lavrion is a unique site for education and research in several disciplines, starting from geological investigation, prospecting, mineralogy, geochemistry, mining, ore beneficiation, metallurgical processes, economic, political, and social sciences. Most importantly, what makes Lavrion even more impressive is that the combination of all the aforementioned disciplines can be demonstrated and thus give a better understanding of the overall production chain.

\subsection{Preservation of the Natural Geoheritage}

Lavrion is a geoheritage, a term defined as the array of geological features, dynamics, sites, and landscapes that are not only key-indicators of the Earth's history and functional processes but that also reflect the interactions between abiotic and biotic systems, including the anthroposystem. As a geo-antroposystem, Lavrion is an "interactive system composed of ecosystems and the societies that live in and use them" with an emphasis on the interaction and the co-evolution between natural systems and social systems. It allows the production of cross-knowledge between the disciplines of the natural sciences and those of human and social sciences.

The Lavrion district is not only famous because of the mining activity during the past, but it shows also unique mineralogical and petrological features. Lavrion is a natural geological and mineralogical museum. Moreover, the Lavrion deposit comprises five distinct mineralization types occurring close to each other, a feature never observed in any other ore deposit. As a result, Lavrion represents a unique natural laboratory for geological, mineralogical, and geochemical research. For scientists and the public, Lavrion provides an almost inexhaustible field of activity and also offers ideal opportunities for educational and geotourism.

Unfortunately, the extreme beauty, the rarity, and the diversity of Lavrion minerals has led to an extensive commercial mineral exploitation of large underground areas by local and foreign dealers without any control, consequently leading to a dramatic reduction in the abundance of mineral occurrences. The mineralogical heritage is being destroyed for traffic on a European scale and beyond, often destroying scientific information on the geological evolution and valuable elements of the geocultural heritage, making their preservation necessary. 

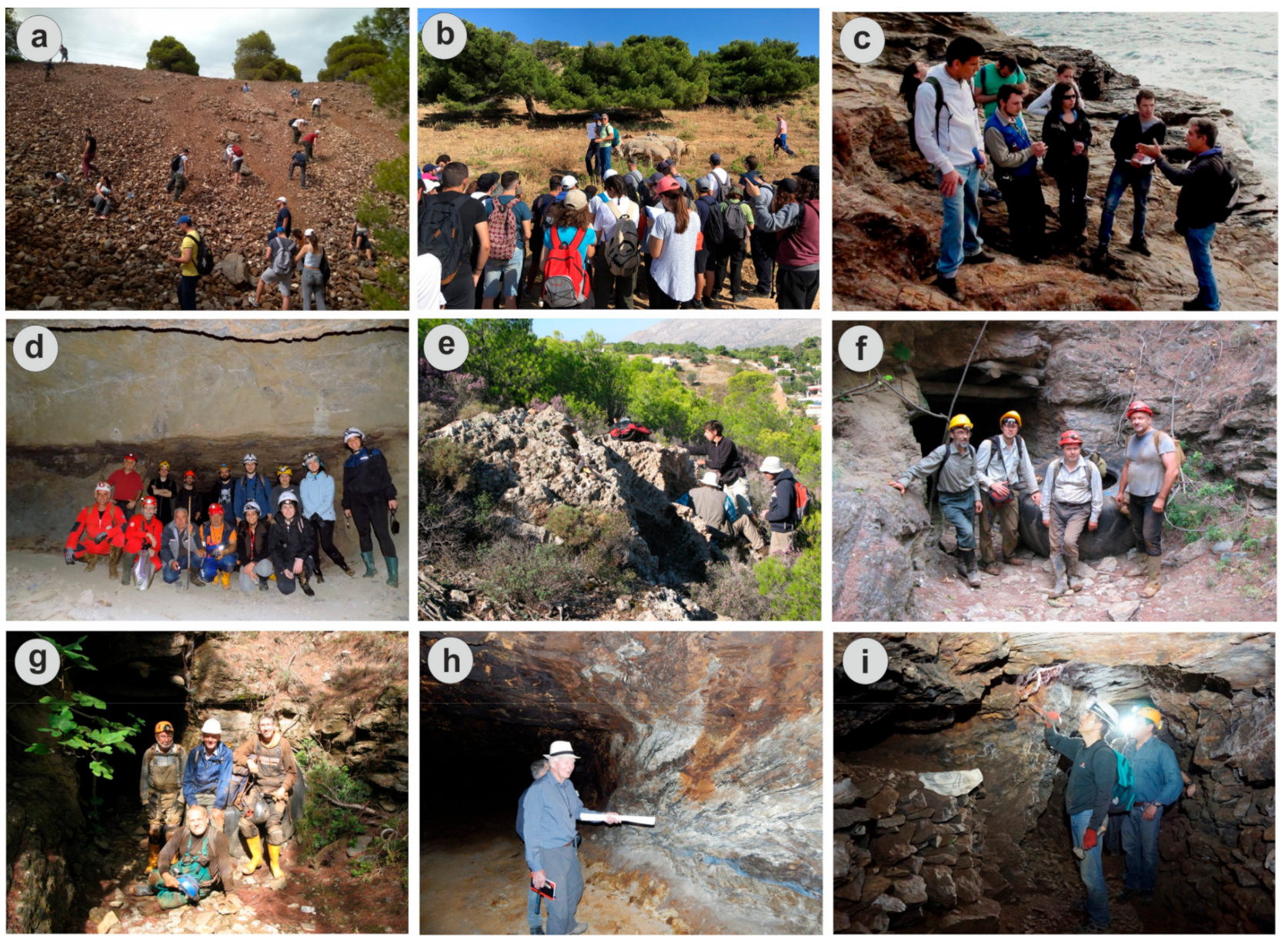

Figure 8. Educational activities at the Lavrion deposit. (a) Undergraduate National and Kapodistrian University of Athens (NKUA) student field trip at Lavrion (June 2018): searching and recognizing minerals at Kamariza mining dumps; (b) undergraduate NKUA student field trip at Lavrion (June 2019): teaching geology and mineralogy at Plaka granodiorite site; (c) postgraduate NKUA student field trip at Lavrion (June 2015): teaching geology and mineralizing processes at the footwall of the West Cycladic detachment at Avlaki; (d) postgraduate Aristotle University of Thessaloniki student field trip at Lavrion (October 2020): teaching geology and mineralizing processes at the footwall of the West Cycladic detachment at Plaka, Villia area; (e) supervising PhD student at porphyry-Mo occurrence of Plaka granodiorite: collaboration between NKUA and University of Lorraine, Nancy, France (October 2013); (f) collaboration between NKUA, Lomonosov Moscow State University, Russia, at Lavrion (October 2013). Underground survey for the identification of new minerals from the Lavrion oxidation zone; entrance of Kamariza main gallery system; (g) collaboration between NKUA, Institut für Mineralogie und Kristallographie der Universität Wien, Austria and Naturhistorisches Museum Wien, Mineralogisch-Petrographische Abt., Austria, at Lavrion (September 2015). Visit in Kamariza main gallery system for study and identification of new minerals from the Lavrion oxidation zone; (h) collaboration between NKUA-School of Earth Sciences, University of Western Australia, École Normale Supérieure de Lyon, France, and Aristotle University of Thessaloniki (October 2016). Pyrrhotite mineralization at Plaka-3D modeling and reassessing Lavrion geology and mineralization; (i) collaboration between NKUA-University of Lorraine, Nancy, France, and Hellenic Survey of Geology \& Mineral Exploration (HSGME) (October 2017). Studying geology and sampling silver ore at Thorikos mine No. 6.

Excavations of still undiscovered mineralized carst voids and the preservation of existing ones are necessary in order to save the content of the geodes and also to reconstruct their genetic evolution during the mineral forming processes. Part of the new finds should remain in situ for local observation, while most of the specimens should be displayed at a new Mineralogy Museum at Lavrion where funding has been secured. A detailed geological mapping underground will help discover new potential sites of minerals formation. Additionally, a detailed registration and mapping of mineral and ore localities both on surface and underground is recommended. 
Today, Lavrion is a fragile and threatened heritage. Some buildings and pieces of machinery from the Industrial Age need to be preserved. The famous archives of the French Mining Company need to be preserved and classified. Ancient archaeological excavations sites are gradually destroyed by erosion. This will have disastrous consequences if no protection is provided over the next few years. It should be mentioned here that a huge number of small shafts (approximately more than 1000) should be located, mapped, stabilized, and be made safe for the safety of visitors both on the surface and underground. Several mines shafts are being filled up by tons of dump material. Restoration of ancient and modern galleries will facilitate their use for touristic and scientific purposes. The Lavrion mining system is one of the best preserved and dry mining systems in the world. It can be used among others as a natural underground, three-dimensional, mineralogical museum, which, in addition to the surface geological, mineralogical, and archaeological sites, can be combined into geotouristic pathways. The development of several geotouristic paths at Lavrion should be a first priority, and it should follow other well described examples both on surface, as, for example, at Sigri, Lesvos, petrified forest Geopark [23,30], as well as underground at, for example, in the Harz Mountains and at Freiberg, Germany. The geotouristic development of mineralogical, geological, archaeological, and metallurgical sites at Lavrion will ensure the preservation of its geological and cultural heritage, promote educational activities, and also offer the opportunity for sustainable development.

Because of the fundamental importance of Athens to the development of democracy, ensuring continuation of a broad range of archaeological, geological, and mineralogical work in and around the ancient mining and processing sites at Lavrion is an even stronger reason for establishing a geopark and providing the associated protection of this invaluable site. The designation as a geopark would facilitate and simplify the immensely necessary work to preserve the archeological and the historical heritage of the area, and it would also provide a solid legal basis regarding how future research is carried out on-site. If the site is thus recognized, it will ensure continuing research and rehabilitation work over the long term.

At Lavrion, man and the Earth share a common heritage, of which we are but the custodians. Each of us should understand that the slightest damage could lead to irreversible losses for the future. In undertaking any form of development, we should respect the singularity of this unique heritage.

Securing such world heritage recognition will ensure that future generations will benefit from an understanding of how mining, mankind's oldest industry, has contributed to the development of society-socially, culturally, economically, and technologicallysince the dawn of the Stone Age.

\section{Conclusions}

The geological, the mineralogical, and the metallogenetic features described here are of great scientific interest, as they give us information about the conditions and the timing of burial metamorphism, the subsequent exhumation paths of the metamorphic core complexes, and the magmatic-hydrothermal and the mineral-forming processes. Furthermore, they can be considered as natural wonders unique in the world. Lavrion belongs to the world mineralogical, geological, mining, and archaeological heritage and can be considered as a mineralogical-petrological treasure trove. The geotouristic development of Lavrion combined with the foundation of a new Mineralogy Museum ensures the preservation of the geological heritage and also offers the opportunity for sustainable development. This district should become part of the Global Network of Natural Geoparks, following a policy which enhances the natural mineral wealth so as to protect and promote it for educational, research, and social purposes. 
Author Contributions: Conceptualization, P.V., A.P., E.M., D.M., J.R.; Investigation and data curation, P.V., V.M., C.M., A.P., E.M., B.R., U.K., A.T., C.S., D.M., O.V., P.G.S., J.R., K.S., M.V., I.V.P., N.V.C., A.M., M.K., A.K., S.Z.; Writing—original draft preparation, P.V., D.M., J.R., A.T., U.K., B.R.; Writing—review and editing, P.V., P.G.S., U.K., C.M.; All authors have read and agreed to the published version of the manuscript.

Funding: This research received no external funding.

Institutional Review Board Statement: Not applicable.

Informed Consent Statement: Not applicable.

Data Availability Statement: The data presented in this study are contained within the article.

Acknowledgments: The authors wish to thank Hercules Katsaros and Vasilios Stergiou for valuable help with providing information on mines during studies of underground workings. Ryan Mathur and one anonymous reviewer are especially thanked for their constructive comments that greatly improved the manuscript. The Guest Editor is acknowledged for the editorial handling of the manuscript. The authors dedicate this article to the memory of our good friends, Alkiviadis Tsolakos and Christos Solomos, who greatly contributed to the knowledge of underground Lavrion.

Conflicts of Interest: The authors declare no conflict of interest.

\section{References}

1. Katerinopoulos, A.; Zissimopoulou, E. Minerals of the Lavrion Mines; The Greek Association of Mineral and Fossil Collectors: Athens, Greece, 1994; pp. 1-304.

2. Rieck, B.; Rieck, P. Lavrion: The complete mineral list. Lapis 1999, 24, 61-63. (In German)

3. Voudouris, P.; Katerinopoulos, A.; Magganas, A. Mineralogical geotopes in Greece: Preservation and promotion of museum specimens of minerals and gemstones. Sofia Initiative "Mineral Diversity Preservation". In Proceedings of the IX International Symposium Mineral Diversity Research and Reservation, Sofia, Bulgaria, 16-18 October 2017; pp. 149-159.

4. Voudouris, P.; Mavrogonatos, C.; Graham, I.; Giuliani, G.; Tarantola, A.; Melfos, V.; Karampelas, S.; Katerinopoulos, A.; Magganas, A. Gemstones of Greece: Geology and Crystallizing Environments. Minerals 2019, 9, 461. [CrossRef]

5. Ottens, B.; Voudouris, P. Griechenland: Mineralien-Fundorte-Lagerstätten; Christian Weise Verlag: Munich, Germany, 2018 ; p. 480. ISBN 978-3-921656-86-0.

6. Klemme, S.; Berndt, J.; Mavrogonatos, C.; Flemetakis, S.; Baziotis, I.; Voudouris, P.; Xydous, S. On the Color and Genesis of Prase (Green Quartz) and Amethyst from the Island of Serifos, Cyclades, Greece. Minerals 2018, 8, 487. [CrossRef]

7. Ducoux, M.; Branquet, Y.; Jolivet, L.; Arbaret, L.; Grasemann, B.; Rabillard, A.; Gumiaux, C.; Drufin, S. Synkinematic skarns and fluid drainage along detachments: The West Cycladic Detachment System on Serifos Island (Cyclades, Greece) and its related mineralization. Tectonophysics 2017, 695, 1-26. [CrossRef]

8. Siron, C.R.; Rhys, D.; Thompson, J.F.H.; Baker, T.; Veligrakis, T.; Camacho, A.; Dalampiras, L. Structural controls on porphyry $\mathrm{Au}-\mathrm{Cu}$ and $\mathrm{Au}-$ rich polymetallic carbonate-hosted replacement deposits of the Kassandra mining district, northern Greece. Econ. Geol. 2018, 113, 309-345. [CrossRef]

9. Marinos, G.; Petrascheck, W.E. Laurium: Geological and geophysical research. Greece. Inst. Geol. Subsurf. Res. 1956, 4, 1-246.

10. Lekkas, S.; Skourtsos, E.; Soukis, K.; Kranis, H.; Lozios, S.; Alexopoulos, A.; Koutsovitsis, P. Late Miocene detachment faulting and crustal extension in SE Attica (Greece). In Geophysical Research Abstracts; EGU General Assembly: Vienna, Austria, 2011; Volume 13, EGU2011-13016.

11. Berger, A.; Schneider, D.A.; Grasemann, B.; Stockli, D. Footwall mineralization during Late Miocene extension along the West Cycladic Detachment System, Lavrion, Greece. Terra Nova 2013, 25, 181-191. [CrossRef]

12. Vourlakos, N.M.; Fitros, M.G. The Minerals of Lavrion; The Scientific Society of Lavreotiki: Lavrion, Greece, 2019; No. 13; ISBN 978-960-85333-6.

13. Ardaillon, E. Les mines du Laurion dans l'Antiquité. In Bibliothèque des Ecoles Françaises d'Athènes et de Rome, Fasc. 77; Thorin et fils: Paris, France, 1897.

14. Conophagos, C. Le Laurium Antique et la Technique Grecque de la Production de l'argent; Ekdotiki Athinon: Athens, Greece, 1980; p. 458.

15. Morin, D.; Photiades, A. L'exploitation des gisements métallifères profonds dans l'Antiquité. Les mines du Laurion (Grèce). In Die Eckart Olshausen/Vera Sauer ( $\mathrm{Hg}$ ) Die Schätze der Erde-Natürliche Ressourcen in der antiken Welt; Olshausen, E., Sauer, V., Eds.; Stuttgarter Kolloquium zur Historischen Geographie des Altertums 10, 2008; Geographica Historica 28; CD-Rom Illustrations; Franz Steiner Verlag: Stuttgart, Germany, 2012; pp. 28-335. ISBN 978-3-515-10143-1.

16. Morin, D.; Herbach, R.; Rosenthal, P. The Laurion shafts, Greece: Ventilation systems and mining technology in antiquity. Hist. Metall. 2012, 46, 9-18.

17. Morin, D.; Delpech, S. Mines and Mining. In Exploring Thorikos; Docter, R.F., Webster, M., Eds.; The Section of Mediterranean Archaeology, Department of Archaeology, Ghent University: Ghent, Belgium, 2018; pp. 41-43. 
18. Morin, D.; Rosenthal, P.; Photiades, A.; Delpech, S.; Jacquemot, D. Aegean Mining Technologies in Antiquity-A Traceological Approach: The Laurion Mines (Greece) In Metallurgy in Numismatics 6-Mines, Metals, and Money Ancient World Studies in Science, Archaeology and History; Sheedy, K.A., Davis, G., Eds.; The Royal Numismatic Society Special Publication: London, UK, 2020; pp. 23-41, No. 56; ISBN 0-901405-37-X.

19. Ross, J.; Voudouris, P.; Melfos, V.; Vaxevanopoulos, M. Mines, Metals and Money in Attica and the Ancient World: The Geological Context. In Metallurgy in Numismatics 6-Mines, Metals, and Money Ancient World Studies in Science, Archaeology and History; Sheedy, K.A., Davis, G., Eds.; The Royal Numismatic Society Special Publication: London, UK, 2020; pp. 9-21, No. 56; ISBN 0-901405-37-X.

20. Gale, N.H.; Stos-Gale, Z.A. Cycladic lead and silver metallurgy. Ann. Br. School Athens 1981, 76, 169-224. [CrossRef]

21. Theodossiou-Drandaki, E. Criteria of Characterizing Geotopes; 1st Symposium on the Conservation of Geological-Geomorphological Heritage: Ermoupolis, Greece, 1996; pp. 70-72. (In Greek)

22. Theodossiou-Drandaki, E. Geological framework for the selection of geotopes according the criteria of the International Association of Geosciences (IUES) and the European Society of conservation of geological and geomorphological Heritage (ProGEO). Bull. Geol. Soc. Greece 2001, 34, 795-803.

23. Velitzelos, E.; Mountrakis, D.; Zouros, N.; Soulakellis, N. Atlas of the Geological Monuments of the Aegean; Ministry of the Aegean: Athens, Greece, 2003; p. 352. (In Greek)

24. Katerinopoulos, A. The Lavrion Mines. In Natural Heritage from East to West; Evelpidou, N., Figueiredo, T., Mauro, F., Vassilopoulos, A., Eds.; Springer: Berlin/Heidelberg, Germany, 2010; pp. 27-33.

25. Moraiti, E.; Staridas, S. Lavrion: One great territory with unique geoheritage as a prospective Geopark. In Proceedings of the European Geopark Conference, Rokua, Finland, 3-6 September 2015; p. 147.

26. Papaspyridakou, P. Type-Locality and Aesthetic Minerals from Lavrion: A New Geopath for Their Quest. Master's Thesis, National and Kapodistrian University of Athens, Athens, Greece, 2013.

27. Papaspyridakou, P.; Katerinopoulos, A.; Voudouris, P.; Magganas, A.; Megremi, I. A geopath in a quest for aesthetic minerals at Lavrion mines. Sofia Initiative "Mineral diversity preservation". In Proceedings of the IX International Symposium Mineral Diversity Research and Reservation, Sofia, Bulgaria, 16-18 October 2017; p. 47.

28. Voudouris, P.; Photiades, A.; Tarantola, A.; Scheffer, C.; Vanderhaeghe, O.; Morin, D.; Vlachopoulos, N. The Lavrion and Serifos mining centers: Two worldwide unique mineralogical and geological monuments and perspectives for their protection. In Proceedings of the Greek ICOMOS Conference: “The Value Framework for the Protection and Management of Sites and Monuments Extracted during the Antiquity: Current Uses and Future Synergies", Athens-Lavrion, Greece, 29-30 November 2019.

29. Periferakis, A.; Paresoglou, I.; Paresoglou, N. The significance of the Lavrion mines in Greek and European Geoheritage. Eur. Geol. 2019, 48, 24-27.

30. Zouros, N. The European Geoparks Network. Geological Heritage protection and local development. Episodes 2004, $27,165-171$. [CrossRef]

31. Moraiti, E. Geotopes-Geoparks in Greece, contribution to sustainable development European Geopark Conference. In Proceedings of the European Geopark Conference, Rokua, Finland, 3-6 September 2015; p. 144.

32. Leleu, M.; Morikis, A.; Picot, P. Sur des mineralisations de type skarn au Laurium (Grèce). Miner. Depos. 1973, 36, 477-489.

33. Economou, M.; Skounakis, S.; Papathanasiou, C. Magnetite deposits of skarn type from the Plaka area of Laurium, Greece. Chemie der Erde 1981, 40, 241-252.

34. Photiades, A.; Carras, N. Stratigraphy and geological structure of the Lavrion area (Attica, Greece). Bull. Geol. Soc. Greece 2001, 34, 103-109. [CrossRef]

35. Photiades, A.; Saccani, E. Geochemistry and tectono-magmatic significance of HP/LT metaophiolites of the Attic-Cycladic zone in the Lavrion area (Attica, Greece). Ofioliti 2006, 31, 89-102.

36. Skarpelis, N. The Lavrion deposit (SE Attica, Greece): Geology, mineralogy and minor elements chemistry. N. Jahr. Miner. Abhandl. 2007, 83, 227-249. [CrossRef]

37. Voudouris, P.; Melfos, V.; Spry, P.G.; Bonsall, T.; Tarkian, M.; Economou-Eliopoulos, M. Mineralogical and fluid inclusion constraints on the evolution of the Plaka intrusion-related ore system, Lavrion, Greece. Miner. Petrol. 2008, 93, 79-110. [CrossRef]

38. Voudouris, P.; Melfos, V.; Spry, P.G.; Bonsall, T.; Tarkian, M.; Solomos, C. Carbonate-replacement Pb-Zn-Ag $\pm \mathrm{Au}$ mineralization in the Kamariza area, Lavrion, Greece: Mineralogy and thermochemical conditions of formation. Miner. Petrol. 2008, 94, 85-106. [CrossRef]

39. Skarpelis, N.; Argyraki, A. Geology and origin of the supergene ore at the Lavrion Pb-Ag-Zn deposit, Attica, Greece. Res. Geol. 2009, 59, 1-14. [CrossRef]

40. Bonsall, T.A.; Spry, P.G.; Voudouris, P.; Tombros, S.; Seymour, K.; Melfos, V. The Geochemistry of Carbonate-Replacement $\mathrm{Pb}-\mathrm{Zn}$-Ag Mineralization in the Lavrion District, Attica, Greece: Fluid Inclusion, Stable Isotope, and Rare Earth Element Studies. Econ. Geol. 2011, 106, 619-651. [CrossRef]

41. Spry, P.G.; Mathur, R.D.; Bonsall, T.A.; Voudouris, P.; Melfos, V. Evidence for Mixing of Re-Os Isotopes at the Lavrion CarbonateReplacement Pb-Zn-Ag deposit, Attica, Greece. Miner. Petrol. 2014, 108, 503-513. [CrossRef]

42. Scheffer, C.; Vanderhaeghe, O.; Lanari, P.; Tarantola, A.; Ponthus, L.; Photiades, A.; France, L. Syn- to post-orogenic exhumation of metamorphic nappes: Structure and thermobarometry of the western Attic-Cycladic metamorphic complex (Lavrion, Greece). J. Geodyn. 2016, 96, 174-193. [CrossRef] 
43. Scheffer, C.; Tarantola, A.; Vanderhaeghe, O.; Voudouris, P.; Rigaudier, T.; Photiadis, A.; Morin, D.; Alloucherie, A. The Lavrion $\mathrm{Pb}-\mathrm{Zn}-\mathrm{Fe}-\mathrm{Cu}-\mathrm{Ag}$ detachment-related district (Attica, Greece): Structural control on hydrothermal flow and element transfer-deposition. Tectonophysics 2017, 717, 607-627. [CrossRef]

44. Scheffer, C.; Tarantola, A.; Vanderhaeghe, O.; Voudouris, P.; Spry, P.G.; Rigaudier, T.; Photiades, A. The Lavrion Pb-Zn-Ag-rich Vein and Breccia Detachment-Related Deposits (Greece): Involvement of Evaporated Seawater and Meteoric Fluids during Post-Orogenic Exhumation. Econ. Geol. 2019, 114, 1415-1442. [CrossRef]

45. Ross, J.; Voudouris, P.; Melfos, V.; Vaxevanopoulos, M.; Soukis, K.; Merigot, K. What did the ancient Greeks mine at Lavrion and when did they mine it? Der Anschnitt 2021, in press.

46. Jolivet, L.; Faccenna, C.; Huet, B.; Labrousse, L.; Le Pourhiet, L.; Lacombe, O.; Lecomte, E.; Burov, E.; Denèle, Y.; Brun, J.-P.; et al. Aegean tectonics: Strain localization, slab tearing and trench retreat. Tectonophysics 2013, 597, 1-33. [CrossRef]

47. Wind, S.C.; Schneider, D.A.; Hannington, M.D.; McFarlane, C.R.M. Regional similarities in lead isotopes and trace elements in galena of the Cyclades Mineral District, Greece with implications for the underlying basement. Lithos 2020, 366, 1-27.

48. Grasemann, B.; Huet, B.; Schneider, D.A.; Rice, A.H.N.; Lemonnier, N.; Tschegg, C. Miocene postorogenic extension of the Eocene synorogenic imbricated Hellenic subduction channel: New constraints from Milos (Cyclades, Greece). Bull. Geol. Soc. Am. 2018, 130, 238-262. [CrossRef]

49. Papanikolaou, D.J. Tectonic evolution of the Cycladic blueschist belt (Aegean Sea, Greece). In Chemical Transport in Metasomatic Processes; Helgeson, H.C., Ed.; NATO ASI series; Springer: Berlin/Heidelberg, Germany, 1987; Volume 218, pp. 429-450.

50. Jolivet, L.; Brun, J.P. Cenozoic geodynamic evolution of the Aegean. Int. J. Earth Sci. 2010, 99, 109-138. [CrossRef]

51. Ring, U.; Glodny, J.; Will, T.; Thomson, S. The Hellenic subduction system: High-pressure metamorphism, exhumation, normal faulting, and large-scale extension. Ann. Rev. Earth Planet. Sci. 2010, 38, 45-76. [CrossRef]

52. Seman, S.; Stockli, D.F.; Soukis, K. The provenance and internal structure of the Cycladic Blueschist Unit revealed by detrital zircon geochronology, Western Cyclades, Greece. Tectonics 2017, 36, 1407-1429. [CrossRef]

53. Coleman, M.J.; Schneider, D.A.; Grasemann, B.; Soukis, K.; Lozios, S.; Hollinetz, M.S. Lateral termination of a Cycladic-style detachment system (Hymittos, Greece). Tectonics 2020, 39, e2020TC006128. [CrossRef]

54. Kruckenberg, S.C.; Vanderhaeghe, O.; Ferré, E.C.; Teyssier, C.; Whitney, D.L. Flow of partially molten crust and the internal dynamics of a migmatite dome, Naxos, Greece. Tectonics 2011, 30, TC3001. [CrossRef]

55. Grasemann, B.; Schneider, D.A.; Stöckli, D.F.; Iglseder, C. Miocene bivergent crustal extension in the Aegean: Evidence from the western Cyclades (Greece). Lithosphere 2012, 4, 23-39. [CrossRef]

56. Stouraiti, C.; Soukis, K.; Voudouris, P.; Mavrogonatos, C.; Lozios, S.; Lekkas, S.; Beard, A.; Strauss, H.; Palles, D.; Baziotis, I.; et al. Silver-rich sulfide mineralization in the northwestern termination of the Western Cycladic Detachment System, at Agios Ioannis Kynigos, Hymittos Mt. (Attica, Greece): A mineralogical, geochemical and stable isotope study. Ore Geol. Rev. $2019,111,102992$. [CrossRef]

57. Altherr, R.; Kreuzer, H.; Wendt, I.; Lenz, H.; Wagner, G.A.; Keller, J.; Harre, W.; Höndorf, A. A late Oligocene/early Miocene high temperature belt in the Attic-Cycladic crystalline complex (SE Pelagonian, Greece). Geol. Jahrb. 1982, 23, 97-164.

58. Pe-Piper, G.; Piper, D.J. The igneous rocks of Greece. The anatomy of an orogen. In Beiträge zur Regionalen Geologie der Erde, Band 30; Gebrüder Borntraeger: Berlin/Stuttgart, Germany, 2002; p. 573.

59. Menant, A.; Jolivet, L.; Vrielynck, B. Kinematic reconstructions and magmatic evolution illuminating crustal and mantle dynamics of the eastern Mediterranean region since the late Cretaceous. Tectonophysics 2016, 675, 103-140. [CrossRef]

60. Reinecke, T.; Altherr, R.; Hartung, B.; Hatzipanagiotou, K.; Kreuzer, H.; Harre, W.; Klein, H.; Keller, J.; Geenen, E.; Boeger, H. Remnants of a Late Cretaceous high temperature belt on the island of Anafi (Cyclades, Greece). N. Jahrbuch Miner. Abhandl. 1982, $145,157-182$.

61. Coleman, M.; Dubosq, R.; Schneider, D.A.; Grasemann, B.; Soukis, K. Along-strike consistency of an extensional detachment system, West Cyclades, Greece. Terra Nova 2019, 31, 220-223. [CrossRef]

62. Tarantola, A.; Scheffer, C.; Vanderhaeghe, O.; Voudouris, P.; Photiades, A.; Morin, D. Geologic and metallogenic overview of the Lavrion mining district: A guide for archaeological exploration. Der Anschnitt 2021, in press.

63. Seman, S.; Soukis, K.; Stockli, D.F.; Skourtsos, E.; Kranis, H.; Lozios, S.; Shin, T. Provenance of metasediments and Miocene exhumation history of the Lavrion Peninsula, South Attica, Greece: A combined structural, (U-Th)/He, and detrital zircon U-Pb study. In Geophysical Research Abstracts; EGU2013-12605; EGU General Assembly: Vienna, Austria, 2013 ; Volume 15.

64. Baltatzis, E. Blueschist-to-greenschist transition and the P-T path of prasinites from the Lavrion area, Greece. Miner. Mag. 1996, 60, 551-561. [CrossRef]

65. Skarpelis, N.; Tsikouras, B.; Pe-Piper, G. The Miocene igneous rocks in the Basal unit of Lavrion (SE Attica, Greece): Petrology and geodynamic implications. Geol. Mag. 2008, 145, 1-15. [CrossRef]

66. Papanikolaou, D.J.; Syskakis, D. Geometry of acid intrusives in Plaka, Laurium and relation between magmatism and deformation. Bull. Geol. Soc. Greece 1991, 25, 355-368.

67. Liati, A.; Skarpelis, N.; Pe-Piper, G. Late Miocene magmatic activity in the Attic-Cycladic Belt of the Aegean (Lavrion, SE Attica, Greece): Implications for the geodynamic evolution and timing of ore deposition. Geol. Mag. 2009, 146, 732-742. [CrossRef]

68. Tsokas, G.N.; Stampolidis, A.; Angelopoulos, A.D.; Kilias, S. Analysis of potential field anomalies in Lavrion mining area, Greece. Geophysics 1998, 63, 1965-1970. [CrossRef] 
69. Voudouris, P.; Mavrogonatos, C.; Rieck, B.; Kolitsch, U.; Spry, P.G.; Scheffer, C.; Tarantola, A.; Vanderhaeghe, O.; Galanos, E.; Melfos, V.; et al. The Gersdorffite-Bismuthinite-Native Gold Association and the Skarn-Porphyry Mineralization in the Kamariza Mining District, Lavrion, Greece. Minerals 2018, 8, 531. [CrossRef]

70. Baltatzis, E. Contact metamorphism of a calcsilicate hornfels from Plaka area, Lavrium, Greece. N. Jahr. Miner. Monatshefte 1981, 1981, 481-488.

71. Voudouris, P.; Economou-Eliopoulos, M. Mineralogy and chemistry of Cu-rich ores from the Kamariza carbonate-hosted deposit (Lavrion), Greece. In Mineral Exploration and Sustainable Development; Eliopoulos, D., Ed.; Millpress: Rotterdam, The Netherlands, 2003; pp. 499-502.

72. Voudouris, P. Gold and silver mineralogy of the Lavrion deposit Attika/Greece. In Mineral Deposit Research: Meeting the Global Challenge; Mao, J., Bierlein, F.P., Eds.; Springer: Berlin/Heidelberg, Germany, 2005; pp. 1089-1092.

73. Kolitsch, U.; Rieck, B.; Voudouris, P. Mineralogy and genesis of the Lavrion ore deposit: New insights from the study of ore and accessory minerals. Mitt. Österr. Miner. Ges. 2015, 161, 66.

74. Rieck, B.; Kolitsch, U.; Voudouris, P.; Giester, G.; Tzeferis, P. More new finds from Lavrion, Greece. Miner. Welt 2018, 29, 32-77. (In German)

75. Rieck, B.; Kolitsch, U.; Voudouris, P.; Giester, G.; Tzeferis, P. Lavrion, Greece: More new finds from the famous mining district. Miner. Welt 2020, 31, 6-21. (In German)

76. Voudouris, P.; Tsolakos, A.; Papanikitas, A.; Solomos, C. New finds from Lavrion 2003. Lapis 2004, 4, 13-15.

77. Solomos, C.; Voudouris, P.; Katerinopoulos, A. Mineralogical studies of a bismuth-gold-antimony mineralization in Kamariza Lavrion. Bull. Geol. Soc. Greece 2004, 36, 387-396. [CrossRef]

78. Katerinopoulos, A.; Solomos, C.; Voudouris, P. Lavrion smithsonites: A mineralogical and mineral chemical study of their coloration. In Mineral Deposit Research: Meeting the Global Challenge; Mao, J., Bierlein, F.P., Eds.; Springer: Berlin/Heidelberg, Germany, 2005; pp. 983-986.

79. Kolitsch, U.; Rieck, B.; Brandstätter, F.; Schreiber, F.; Fabritz, K.H.; Blass, G.; Gröbner, J. Neufunde aus dem alten Bergbau und den Schlacken von Lavrion (I). Miner. Welt 2014, 25, 60-75. (In German)

80. Pekov, I.V.; Chukanov, N.V.; Zadov, A.E.; Voudouris, P.; Magganas, A.; Katerinopoulos, A. Agardite-( $\mathrm{Nd}^{2} \mathrm{NdCu}_{6}\left(\mathrm{AsO}_{4}\right)_{3}\left(\mathrm{OH}_{6} \cdot 3 \mathrm{H}_{2} \mathrm{O}\right.$ from the Hilarion Mine, Lavrion, Greece: Mineral description and chemical relations with other members of the agardite-zálesiite solid-solution system. J. Geo. Sci. 2011, 57, 249-255.

81. Chukanov, N.V.; Pekov, I.V.; Zadov, A.E. Attikaite, $\mathrm{Ca}_{3} \mathrm{Cu}_{2} \mathrm{Al}_{2}\left(\mathrm{AsO}_{4}\right)_{4}(\mathrm{OH})_{4} \cdot 2 \mathrm{H}_{2} \mathrm{O}$, a new mineral species. Geol. Ore Deposits 2007, 49, 720-726. [CrossRef]

82. Giester, G.; Rieck, B. Drobecite, a novel mineral from the Lavrion, Greece, deposit. In Proceedings of the 20th General Meeting of IMA, Budapest, Hungary, 21-27 August 2010.

83. Dittler, E.; Köchlin, R. Über Glaukokerinit, ein neues Mineral von Laurion. Centralbl. Miner. Geol. Paläont. 1932, 1, $13-17$.

84. Pekov, I.V.; Chukanov, N.V.; Yapaskurt, V.O.; Rusakov, V.S.; Belakovskiy, D.I.; Turchkova, A.G.; Voudouris, P.; Magganas, A.; Katerinopoulos, A. Hilarionite, $\mathrm{Fe}^{3+}{ }_{2}\left(\mathrm{SO}_{4}\right)\left(\mathrm{AsO}_{4}\right)(\mathrm{OH}) \cdot 6 \mathrm{H}_{2} \mathrm{O}$, a new supergene mineral from Lavrion, Greece. Geol. Ore Deposits 2013, 56, 567-575. [CrossRef]

85. Chukanov, N.V.; Pekov, I.V.; Möckel, S.; Mukhanova, A.A.; Belakovsky, D.I.; Levitskaya, L.A.; Bekenova, G.K. Kamarizaite, $\mathrm{Fe}^{3+}{ }_{3}\left(\mathrm{AsO}_{4}\right)_{2}(\mathrm{OH})_{3} \cdot 3 \mathrm{H}_{2} \mathrm{O}$, a new mineral species, arsenate analogue of tinticite. Geol. Ore Deposits 2010, 52, 599-605. [CrossRef]

86. Krause, W.; Bernhardt, H.-J.; Braithwaite, R.S.W.; Kolitsch, U.; Pritchard, R. Kapellasite, $\mathrm{Cu}_{3} \mathrm{Zn}(\mathrm{OH})_{6} \mathrm{Cl}_{2}$, a new mineral from Lavrion, Greece. Miner. Mag. 2006, 70, 329-340. [CrossRef]

87. Chukanov, N.V.; Pekov, I.V.; Belakovskiy, D.I.; Britvin, S.N.; Stergiou, V.; Voudouris, P.; Magganas, A. Katerinopoulosite, $\left(\mathrm{NH}_{4}\right)_{2} \mathrm{Zn}\left(\mathrm{SO}_{4}\right)_{2} \cdot 6 \mathrm{H}_{2} \mathrm{O}$, a new mineral from the Esperanza mine, Lavrion, Greece. Eur. J. Miner. 2018, 30, 821-826. [CrossRef]

88. Rieck, B.; Giester, G.; Lengauer, C.; Nasdala, L. Katsarosite, IMA 2020-014, in CNMNC Newsletter 57. Eur. J. Miner. 2020, $32,495$. [CrossRef]

89. Kokkoros, P. Ktenasit, ein Zink-Kupfersulfat aus Lavrion (Griechenland). Tschermaks Miner. Petrogr. Mitt. 1950, 1, 342-346. (In German) [CrossRef]

90. Köchlin, R. Ueber Phosgenit und ein muthmasslich neues Mineral vom Laurion. Annal. K.K. Naturhist. Hofmuseums 1887, 2, 185-190. (In German)

91. Rieck, B.; Lengauer, C.L.; Giester, G. Voudourisite, $\mathrm{Cd}\left(\mathrm{SO}_{4}\right) \cdot \mathrm{H}_{2} \mathrm{O}$, and lazaridisite, $\mathrm{Cd}_{3}\left(\mathrm{SO}_{4}\right)_{3} \cdot 8 \mathrm{H}_{2} \mathrm{O}$, two new minerals from the Lavrion Mining District, Greece. Miner. Mag. 2019, 83, 551-559. [CrossRef]

92. Giester, G.; Rieck, B. Mereiterite, $\mathrm{K}_{2} \mathrm{Fe}\left[\mathrm{SO}_{4}\right]_{2} \cdot 4 \mathrm{H}_{2} \mathrm{O}$, a new leonite-type mineral from the Lavrion Mining District, Greece. Eur. J. Miner. 1995, 7, 559-566. [CrossRef]

93. Witzke, T.; Pöllmann, H.; Vogel, A. Natroglaucocerinite, $\left[\mathrm{Zn}_{5} \mathrm{Al}_{3}(\mathrm{OH})_{16}\right]\left[\left(\mathrm{SO}_{4}\right)_{1.5} \mathrm{Na}_{1.5}\left(\mathrm{SO}_{4}\right)_{0.75}\left(\mathrm{H}_{2} \mathrm{O}\right)_{9}\right]$. Joint Committee on Powder Diffraction, Grant-in-Aid Report. 1996; Number 48-1849.

94. Pekov, I.V.; Chukanov, N.V.; Varlamov, D.A.; Belakovskiy, D.I.; Turchkova, A.G.; Voudouris, P.; Katerinopoulos, A.; Magganas, A. Nickeltsumcorite, $\mathrm{Pb}\left(\mathrm{Ni}, \mathrm{Fe}^{3+}\right)_{2}\left(\mathrm{AsO}_{4}\right)_{2}\left(\mathrm{H}_{2} \mathrm{O}, \mathrm{OH}\right)_{2}$, a new tsumcorite-group mineral from Lavrion, Greece. Miner. Mag. 2014, 80, 337-346. [CrossRef]

95. Giester, G.; Rieck, B.; Brandstätter, F. Niedermayrite, $\mathrm{CdCu}_{4}\left[(\mathrm{OH})_{6} \mid\left(\mathrm{SO}_{4}\right)_{2}\right] \cdot 4 \mathrm{H}_{2} \mathrm{O}$, a new mineral from the Lavrion mining district, Greece. Miner. Petrol. 1998, 63, 19-34. [CrossRef] 
96. Kolitsch, U.; Sejkora, J.; Topa, D.; Kampf, A.R.; Plášil, J.; Rieck, B.; Fabritz, K.H. Prachařite, IMA 2018-081. CNMNC Newsletter No. 46. Miner. Mag. 2018, 82, 1369-1379.

97. Des Cloizeaux, M. Étude de différents minéraux. Bull. Soc. Minér. Fr. 1881, 4, 89-96. (In French) [CrossRef]

98. Rieck, B.; Giester, G.; Lengauer, L.C.; Chanmuang, C.N.; Topa, D. Stergiouite, $\mathrm{CaZn}_{2}\left(\mathrm{AsO}_{4}\right)_{2} \cdot 4 \mathrm{H}_{2} \mathrm{O}-\mathrm{A}$ new mineral from the Lavrion Mining District, Greece. Miner. Petrol. 2020, 114, 319-327. [CrossRef]

99. Damour, A. Essais chimiques et analyse d'un sulfate basique d'Alumine et de Zinc hydraté, nouvelle espèce minérale. Bull. Soc. Minéral. Fr. 1881, 4, 136-138. (In French) [CrossRef]

100. Chukanov, N.V.; Pushcharovsky, D.Y.; Zubkova, N.V.; Pekov, I.V.; Pasero, M.; Merlino, S.; Möckel, S.; Rabadanov, M.K.; Belakovskiy, D.I. Zincolivenite $\mathrm{CuZn}\left(\mathrm{AsO}_{4}\right)(\mathrm{OH})$ : A new adamite-group mineral with ordered distribution of $\mathrm{Cu}$ and $\mathrm{Zn}$. Doklady Earth Sci. 2007, 415A, 841-845. [CrossRef]

101. Witzke, T.; Raade, G. Zincowoodwardite, $\left[\mathrm{Zn}_{1-\mathrm{x}} \mathrm{Al}_{\mathrm{x}}(\mathrm{OH})_{2}\right]\left[(\mathrm{SO} 4)_{\mathrm{x} / 2}\left(\mathrm{H}_{2} \mathrm{O}\right)_{\mathrm{n}}\right]$, a new mineral of the hydrotalcite group. N. Jahrbuch Miner. Mon. 2000, 10, 455-465.

102. Gelaude, P.; van Kalmthout, P.; Rewitzer, C. Laurion: The Minerals in the Ancient Slags; Janssen: Leiden, The Netherlands, 1996; p. 195.

103. Siidra, O.I.; Krivovichev, S.V.; Chukanov, N.V.; Pekov, I.V.; Magganas, A.; Katerinopoulos, A.; Voudouris, P. The crystal structure of $\mathrm{Pb}_{5}\left(\mathrm{As}^{3+} \mathrm{O}_{3}\right) \mathrm{Cl}_{7}$ from ancient slags of Lavrion, Greece-A novel $\mathrm{Pb}(\mathrm{II})$ chloride arsenite. Miner. Mag. 2011, 75, 337-345. [CrossRef]

104. Siidra, O.I.; Chukanov, N.V.; Pekov, I.V.; Krivovichev, S.V.; Katerinopoulos, A.; Voudouris, P.; $\mathrm{Magganas} \mathrm{A} . \mathrm{Pb}_{2}\left(\mathrm{AsO}_{2} \mathrm{OH}\right) \mathrm{Cl}_{2}$, a new phase from the Lavrion ancient slags, Greece: Occurrence and characterization. Miner. Mag. 2012, 76, 597-602. [CrossRef]

105. Zubkova, N.V.; Chukanov, N.V.; Pekov, I.V.; Van, K.V.; Pushcharovsky, D.Y.; Katerinopoulos, A.; Voudouris, P.; Magganas, A. The crystal structure of the compound $\mathrm{Pb} 6 \mathrm{Cu}+(\mathrm{AsO} 3) 2 \mathrm{Cl} 7$ discovered in the ancient slags of Lavrion, Greece. Zeitschr. Kristall.-Crystall. Mat. 2015, 230, 145-149. [CrossRef]

106. Koshlyakova, N.N.; Zubkova, N.V.; Pekov, I.V.; Giester, G.; Pushcharovsky, D.Y.; Chukanov, N.V.; Voudouris, P.; Magganas, A.; Katerinopoulos, A. Crystal chemistry of a nickel-dominant analogue of lyonsite from slags of Lavrion, Greece. N. Jahrb. Miner. Abhandl. 2016, 193, 113-120. [CrossRef]

107. Koshlyakova, N.N.; Zubkova, N.V.; Pekov, I.V.; Giester, G.; Pushcharovsky, D.Y.; Chukanov, N.V.; Voudouris, P.; Magganas, A.; Katerinopoulos, A. Vanadate Garnets from Old Metallurgical Slags of Lavrion, Greece: Solid Solutions and Crystal Structure; Abstracts of the Moscow International School of Earth Sciences; Vernadsky Institute of Geochemistry and Analytical Chemistry: Moscow, Russia, 2016; pp. 137-138.

108. Koshlyakova, N.N.; Zubkova, N.V.; Pekov, I.V.; Giester, G.; Pushcharovsky, D.Y.; Chukanov, N.V.; Voudouris, P.; Magganas, A.; Katerinopoulos, A. Crystal chemistry of vanadate garnets from old metallurgical slags of Lavrion, Greece: Solid solutions and crystal structure. N. Jahrb. Miner. Abhandl. 2016, 194, 19-23. [CrossRef]

109. Siidra, O.I.; Nekrasova, D.O.; Chukanov, N.V.; Pekov, I.V.; Yapaskurt, V.O.; Katerinopoulos, A.; Voudouris, P.; Magganas, A.; Zaitsev, A.N. The hydrocerussite-related phase $\mathrm{NaPb}_{5}\left(\mathrm{CO}_{3}\right)_{4}(\mathrm{OH})_{3}$ from the ancient slags of Lavrion, Greece. Miner. Mag. 2018, 82, 809-819. [CrossRef]

110. Zubkova, N.V.; Chukanov, N.V.; Pekov, I.V.; Pushcharovsky, D.Y.; Katerinopoulos, A.; Voudouris, P.; Magganas, A. New data on fiedlerite-1A from ancient slags of Lavrion, Greece: Crystal structure and hydrogen bonding. Doklady Earth Sc. 2019, 486, 517-520. [CrossRef]

111. Voudouris, P.; Tarantola, A.; Pouliou, M.; Scheffer, C.; Vanderhaeghe, O.; Photiades, A.; Morin, D. Analysis of Ores from Mine 3 at Ari (Anavyssos / Attica): The Mineralogy of galena-sphalerite ores from mine Ari 3 at Charvalos area and comparison to other silver-rich ores from Lavrion district, Greece. In Proceedings of the International Conference "Ari and the Laurion from Prehistoric to Modern Times", Ruhr-Universität Bochum, Bochum, Germany, 11 January 2019; p. 9.

112. Duchène, S.; van Liefferinge, K.; Kayafa, M. The Ore-Processing Workshops. In Exploring Thorikos; Roald, F., Maud, Eds.; The Section of Mediterranean Archaeology, Department of Archaeology, Ghent University: Ghent, Belgium, 2018 ; pp. $43-45$.

113. Kakavogianne, O.; Douni, K.; Georgakopoulou, M. The cupellation of argentiferous lead in Mesogeia, East Attica, during prehistoric times. In Proceedings of the International Conference "Ari and the Laurion from Prehistoric to Modern Times", Ruhr-Universität Bochum, Bochum, Germany, 11 January 2019; pp. 3-4.

114. Gale, N.H.; Kayafa, M.; Stos-Gale, Z.A. Further evidence for Bronze Age production of copper from ores in the Lavrion ore district, Attica, Greece. In Proceedings of the 2nd International Conference: Archaeometallurgy in Europe, Aquileia, Italy, 17-21 June 2007; pp. 158-176.

115. Markouli, A. 19th/20th Cent. Mining and metallurgy in Lavrion. In Proceedings of the International Conference "Ari and the Laurion from Prehistoric to Modern Times", Ruhr-Universität Bochum, Bochum, Germany, 11 January $2019 ;$; p. 14. 